
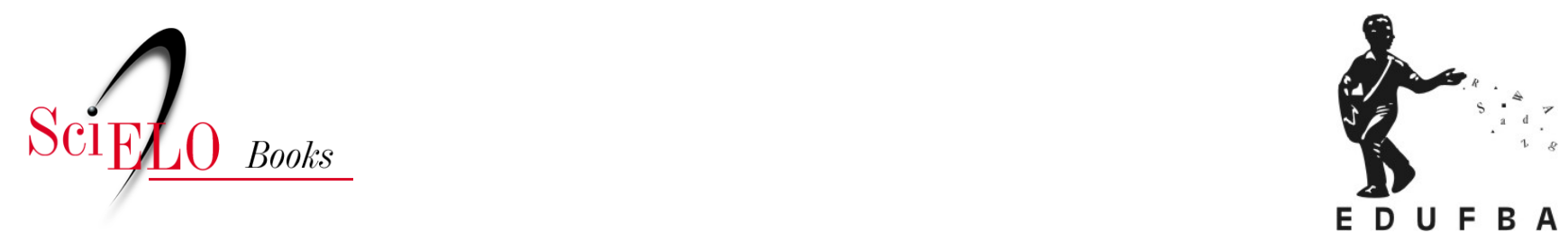

\title{
Hip-hop é também coisa de menina? \\ Convenções de gênero e mulheres jovens no movimento hip hop soteropolitano
}

\author{
Rebeca Sobral Freire
}

\section{SciELO Books / SciELO Livros / SciELO Libros}

FREIRE, R.S. Hip-hop é também coisa de menina? Convenções de gênero e mulheres jovens no movimento hip hop soteropolitano. In: Hip-hop feminista? Convenções de gênero e feminismos no movimento Hip-hop soteropolitano [online]. Salvador: EDUFBA/NEIM, 2018. Bahianas collection, $\mathrm{n}$. 20, pp. 77-128. ISBN: 978-85-232-1862-1. https://doi.org/10.7476/9788523218621.0005.

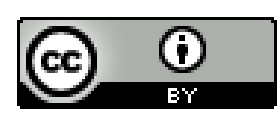

All the contents of this work, except where otherwise noted, is licensed under a Creative Commons Attribution $\underline{4.0 \text { International license. }}$

Todo o conteúdo deste trabalho, exceto quando houver ressalva, é publicado sob a licença Creative Commons Atribição 4.0. 


\section{HIP-HOP É TAMBÉM COISA DE MENINA ? ${ }_{32}$ convenções de gênero e mulheres jovens no movimento hip hop soteropolitano}

Este capítulo tem por objetivo analisar as convenções de gênero que orientam as concepções de feminilidade e de masculinidade forjadas a partir de experiências vivenciadas no âmbito do movimento Hip-hop soteropolitano, na perspectiva das mulheres militantes. Dessa forma, serão realizadas duas tarefas: a de compreender como se expressam as convenções de gênero a partir da militância dessas mulheres, e como essa militância transforma ou reforça essas convenções de gênero nesse movimento e na sociedade.

Convenções de gênero são aqui compreendidas como

o conjunto de valores e ideais relativos ao imaginário sexual disponíveis na cultura e compartilhados, a partir dos quais os seres sociais pautam as suas ações e concepções de mundo, reproduzem e recriam estas mesmas convenções e suas práticas. (BONETTI; FONTOURA, 2007, p. 68)

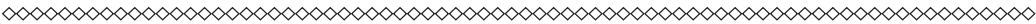

32 Expressão colhida no nome do grupo de mulheres do movimento Hip-hop, que serviu como uma chave analítica, a qual tomei de empréstimo para uso no debate das convenções de gênero na pesquisa. 
Sendo assim, compreendo o universo do Hip-hop como um espaço em que tais convenções estão presentes, nas mais diversas manifestações, conforme aponta Angela Maria de Souza (1998). Em sua pesquisa etnográfica, a autora aponta que o hip-hop tem regulamentações de códigos verbais, gestuais e de vestuário que são linguagens possíveis de serem compreendidas apenas por iniciados nas artes do movimento. O que também foi apontado por Fernanda Noronha (2007) em sua pesquisa etnográfica sobre o hip-hop paulista, ao afirmar que ser membro de um grupo hip-hop implica em compartilhamento de características como faixa etária, gostos musicais, percursos urbanos, circuito de amizade, e até ter origem nas "quebradas", como é chamada a periferia na "gíria" do Movimento, entre outros termos.

Nas observações em campo e no interesse em registrar as experiências das jovens hip hoppers soteropolitanas, oportunizei contatos com redes de movimentos de mulheres e jovens do movimento Hip-hop. A partir da observação das convenções encontradas, pode-se perceber o que se entende ser os modelos de feminilidade e de masculinidade e seus repertórios de ação no hip-hop. Para esse trabalho foram escolhidos casos vinculados aos elementos artísticos do hip-hop, entre eles, o rap, grafiti, break e militância, relatados pelas jovens entrevistadas.

Nesse sentido, as falas e ações das entrevistadas são traduzidas em dados etnográficos importantes que permitem a análise de gênero sob as relações de poder voltadas para os aspectos relacionados à masculinidade e a feminilidade nesse movimento, pois segundo Maria Naomi Castilho Brito (2001, p. 292): “A partir da perspectiva de gênero, têm sido priorizadas as investigações históricas e sociológicas que procurem incorporar as dimensões do masculino e do feminino na análise de forma relacional". Compreendo que essa perspectiva de gênero determina relações de poder que estão em constante negociação e podem alcançar 
distintas configurações a depender do local e dos grupos em questão.

Porém, vale ressaltar que esse olhar de gênero sob essas convenções terá uma interpretação baseada em um comprometimento feminista. Cecilia Sardenberg (2002, p. 90) explica que essa proposta política - científica feminista - tem como base "[...] um saber alavancado em uma perspectiva critica feminista de gênero". Contudo, para alcançar esse objetivo são necessários critérios que envolvem a postura da pesquisadora em campo, sua relação com a comunidade acadêmica e com o universo pesquisado, além da própria investigação etnográfica. (BONETTI, 2007)

O posicionamento para um feminismo jovem interage com a multifacetada realidade e visualiza questões específicas da juventude e das jovens mulheres, com suas diversas subjetividades. Subjetividades essas vinculadas de forma marcante à sexualidade e à negritude diante da identidade de jovens negras que afirmam questões específicas a suas demandas e pautas de sujeitos políticos. (ZANETTI; SOUZA, 2009; ÁVILA, 2000)

Para tanto, a partir da busca pela compreensão acerca das convenções de gênero no movimento Hip-hop soteropolitano, o foco é compreender se e como hip-hop também é coisa de menina, conforme apontaram minhas interlocutoras. Essa questão foi alvo das próprias hip hoppers locais quando realizaram, em Salvador, no ano de 2010, o Seminário ${ }^{33}$ Lugar de mulher é também no Hip-hop. ${ }^{34}$

O objetivo desse evento foi o de reunir mulheres de atuação no hip-hop na cidade para propor que juntas fomentem a construção

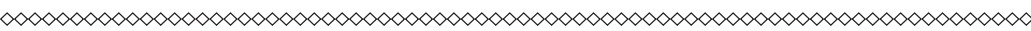

33 Contudo, esse seminário teve atenção especial no trabalho de campo, sobretudo por ter sido o espaço em que realizei registros etnográficos e apliquei as últimas entrevistas em campo. Esse evento foi produzido coletivamente pelo Núcleo Hip-Hop Coisa de Menina, com apoio do Fórum Estadual de Juventude Negra e a Posse de Conscientização e Expressão (PCE).

34 Referência ao slogan feminista que reivindica o espaço para as mulheres na política, seja na política institucionalizada ou em experiências diversas, que relacionem mulheres e política como espaços privilegiados de poder. 
de mecanismos para a legitimação, profissionalização e fortalecimento das mulheres do hip-hop local. Além disso, há uma ligação com uma articulação regional que visa discutir a participação dessas mulheres no I Encontro de Gênero e Hip-Hop Norte e Nordeste ${ }^{35}$ e também a necessidade em dar continuidade a realizações dos encontros estaduais de gênero.

Por isso, este capítulo utiliza o título "Hip-hop é também coisa de menina", que se remete ao Núcleo Hip-hop Coisa de Menina, afinado ao objetivo desta proposta de investigação. $\mathrm{Na}$ fala das interlocutoras esteve corrente a preocupação em refletir acerca do que convém ser do feminino e do masculino na sociedade e também no hip-hop, a partir de suas críticas sobre essas fronteiras e novos ajustes dessa relação.

Portanto, a pergunta "Hip-hop também é coisa de menina?" permitiu o contato com ideias e experiências das mulheres e homens, compartilhando reflexões acerca das concepções de feminilidade e de masculinidade ensejadas no interior do movimento Hip-hop soteropolitano. Com o olhar da perspectiva das jovens hip hoppers, foram priorizadas a atenção sobre pontos de vista e aspectos que explicitassem suas visões de mundo e desafios para as mulheres adentrarem no universo hip-hop.

Em Salvador, há uma série de mulheres que registram sua presença nesse segmento do movimento social jovem, de forma a demarcarem seu espaço, como a influenciarem em ações e pautas do mesmo. Entretanto, essa relação não é exatamente harmônica em se tratando das noções que identificam e diferenciam aspectos entre feminilidade e masculinidade forjadas dentro do movimento. Ou seja, é a partir das convenções de gênero vivenciadas no interior do movimento que se criam modelos com regras,

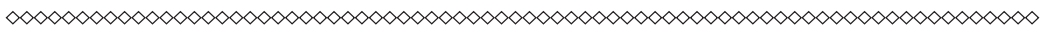

35 Segundo Mara Asantwaa, esse era um dos objetivos do seminário, o de articular mulheres para ir a esse I Encontro de Gênero e Hip Hop Norte e Nordeste, entretanto, este não foi alcançado devido à desarticulação do próprio encontro. 
limites e novas configurações, que por sua vez definem ou identificam o que convém ser coisa de ser menina ou coisa de menino para integrantes do hip-hop.

Figura 1 - Abertura do Seminário Lugar de mulher é também no Hip-hop

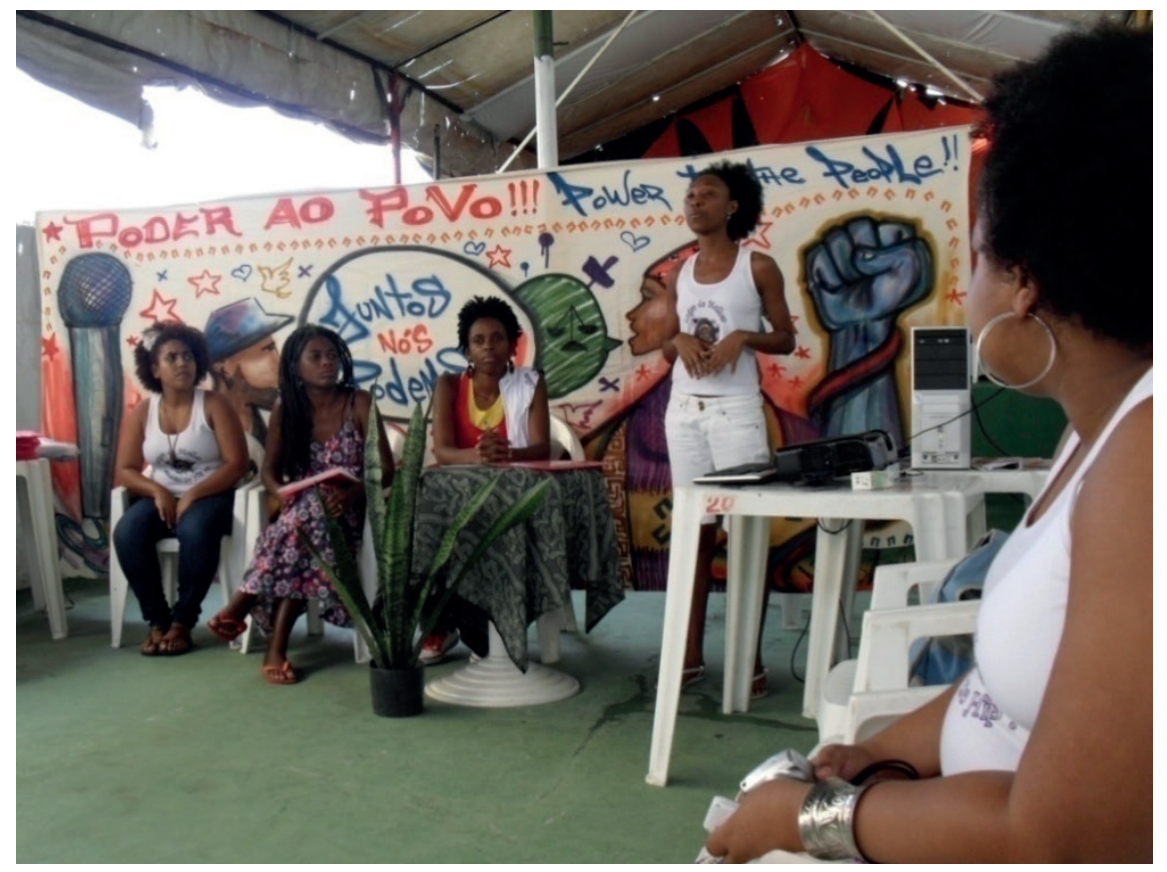

Fonte: produzido pela autora (ago. 2010).

Composto apenas por mulheres, o núcleo Hip-hop Coisa de menina é resultado de uma articulação recente, interessada em reanimar o debate de gênero dentro do movimento Hip-hop soteropolitano e também nos âmbitos estadual e regional. É importante frisar que essas mulheres militantes desse específico grupo são integrantes do movimento com longa experiência de articulação no movimento de mulheres do Hip-hop, pertencentes aos primeiros grupos da cidade, inclusive responsáveis pela realização dos três primeiros encontros estaduais de 
mulheres e hip-hop, e por inúmeras reuniões de mulheres nesse movimento em Salvador, além de integrarem núcleos exclusivos de mulheres em posses mistas de hip-hop, a exemplo do Núcleo de Mulheres da Rede Aiyê Hip-Hop ${ }^{36}$ e do Núcleo de Mulheres da Posse Consciência e Expressão (PCE) ${ }^{37}$

Para contextualizar o movimento de mulheres do hip-hop até o momento do Seminário citado acima, é apresentado um levantamento panorâmico sobre suas ações em Salvador, o qual revela uma intensa articulação política do movimento e das hip hoppers ao priorizarem "as mulheres" como pauta. Para conhecimento, são exibidos registros que pretendem fazer uma breve retrospectiva panorâmica do movimento de mulheres hip hoppers.

A experiência do movimento com os encontros de gênero e hip-hop, ocorridos entre os anos de 2003 a 2005, promoveu uma mudança crucial no papel de atuação feminina no hip-hop baiano. O resultado foi de contribuições no avanço de questões como reconhecimento e luta pelo espaço das mulheres no hip-hop. Esses encontros destacam um aspecto identitário do hip-hop soteropolitano e baiano no que diz respeito à prioridade de espaço para a discussão de gênero e sobre as mulheres, pois não foram encontrados registros de encontros que reunissem tais características em outros estados brasileiros.

No intervalo dos, praticamente, últimos cinco anos, de 2006 a 2010, ocorreu um recolhimento ou diminuição de ações específicas do movimento de mulheres e geral do hip-hop em Salvador, em relação aos anos anteriores de intensa agitação no cenário hip-hop, constantemente visto em suas intervenções pela cidade. Nesse primeiro período, nos anos de 1996 a 2005, o hip-hop

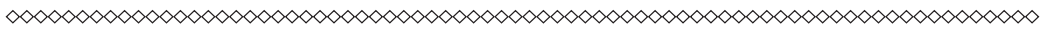

36 Um grupo específico de mulheres dentro de uma Rede em que reúne vários grupos mistos (homens e mulheres) do hip-hop, chamada Rede Aiyê Hip-Hop.

37 Um grupo específico de mulheres dentro da Posse Consciência e Expressão (PCE), que é uma posse mista e uma das integrantes da Rede Aiyê Hip-Hop. 
realizava encontros estaduais, nordestinos, e até nacionais, a exemplo do "Painel de Direitos Autorais". ${ }^{38}$ Esses encontros reuniram jovens da capital e do interior para discussões em torno das questões de organização do movimento e de fomento dos seus elementos artísticos. Na realidade, há uma nova conjuntura a partir de novas formas de articulações em outros espaços e estratégias de ações do movimento.

Este período mais recente culminou em uma desarticulação de uma grande parte do movimento soteropolitano, e um segmento específico, e de maior ação em Salvador e no Estado, até então tratando particularmente da Rede Aiyê Hip-Hop. Essa rede continua ativa, mas em articulações mais tímidas ou mesmo fechadas ou em espaços virtuais (lista de e-mail do grupo), distinta das intensas atividades que aconteciam nos primeiros anos após o desmembramento da Posse Ori, no centro da cidade.

No que trata diretamente de realizações de atividades com caráter de reunião ou encontro, de espaço para debate, discussões e construções de pautas direcionadas para o movimento de mulheres do hip-hop, mesmo que de âmbito local, ocorreram eventos pontuais diante da desarticulação dos próprios núcleos de mulheres de distintas posses. Esse cenário é resultado de uma desarticulação de alguns segmentos do movimento Hip-hop e de outros movimentos sociais. No que se trata de mulheres do hip-hop, pode-se dizer que houve um enfraquecimento dos segmentos do movimento que priorizavam o estímulo à participação das mulheres no hip-hop e a inserção dos debates sobre gênero em suas atividades.

Houve o acompanhamento de reuniões do Núcleo de Mulheres da Rede Aiyê Hip-Hop durante algumas oportunidades. Era

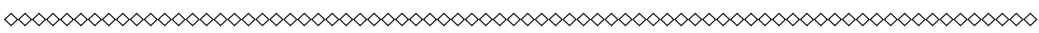

380 movimento Hip-hop baiano também se antecipou às articulações nacionais, impulsionado a formação do "I Painel de Direitos Autorais", em 2006, que contou com a presença de especialistas em direitos autorais e de gravadoras que discutiram com o público sobre o assunto, contando com a participação de Gaspar, representante do grupo de rap paulista Z'africa Brasil. 
corrente o grupo ter dificuldades para realizar seus encontros sob justificativas em torno da falta (falha) de comunicação, o escasso dinheiro para o transporte e da desmotivação pelo esvaziamento dos espaços de reunião. Era comum o atraso em torno do horário das reuniões, como o reduzido número de membros presentes. Nos últimos encontros, era perceptível o enfraquecimento do Núcleo de Mulheres da Rede Aiyê Hip-Hop.

\begin{abstract}
A situação tornou-se mais complicada após o cancelamento das reuniões abertas da Rede Aiyê Hip-Hop, por volta do ano de 2006 e 2007, que aconteciam na Praça do Passeio Público ${ }^{39}$ reunindo integrantes do movimento, parceiros, convidados e curiosos transeuntes neste local, no centro da cidade. Esse espaço misto era um local de encontrar pessoas e planejar ações específicas que envolviam os núcleos que compunham a Rede. Esses núcleos eram: Núcleo de Mulheres, Núcleo de Grafite e Núcleo de Comunicação. (Diário de campo, 16 ago. 2010)
\end{abstract}

Nos anos de 2006 a 2011, o movimento de mulheres do hip-hop não se intimidou pelas barreiras e realizou pontuais atividades específicas das hip hoppers, a exemplo do curso de inglês "I have a dream" e do curso de formação de b-girls, nos respectivos anos de 2007 e 2008. Ambas ações exclusivas do Núcleo de Mulheres da Rede Aiyê Hip-Hop e parcerias.

O curso de inglês "I have a dream" ocorreu durante o ano de 2007. Consistia em um curso de inglês básico voltado para integrantes do movimento Hip-hop e de outros segmentos do movimento Negro. Foi uma iniciativa do Núcleo de Mulheres da Rede Aiyê Hip-Hop e parcerias do movimento de mulheres, voltado para um público estudantil composto por homens e mulheres ligados a movimentos sociais e ao hip-hop, bem como estudantes da UFBA.

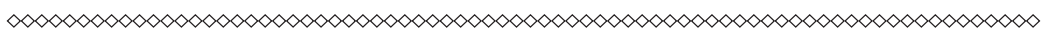

39 A Praça do Passeio Público, no centro da cidade, foi o cenário para muitos movimentos culturais em Salvador, além do Hip Hop, muitos movimentos culturais de música e teatro. 
O curso de formação de $b$-girls,${ }^{40}$ com duração de três meses, no início de 2008, foi o primeiro curso de break para mulheres na América Latina. Foi promovido pelo Núcleo de Mulheres da Rede Aiyê Hip-Hop em parceria com o Fundo Angela Borba de Recursos para Mulheres, ${ }^{41}$ e do Centro de Estudos Afro-Orientais (CEAOUFBA). A turma era formada por 25 mulheres jovens, de 11 a 30 anos, oriundas de bairros populares de Salvador, as quais tiveram, durante o período de janeiro a abril, uma iniciação nas técnicas e estilos básicos da dança de rua em paralelo a oficinas temáticas sobre gênero, raça e sexualidades. O objetivo foi incentivar a formação de um maior número de mulheres dançando break, as novas $b$-girls.

Além desses cursos ocorreu, em 2008, o III Encontro de grafiteiras, que reuniu mulheres brasileiras e latinas. Nesse período, no ano de 2009, também ocorreu o I Encontro de Jovens Feministas Negras em Salvador, no qual muitas hip hoppers soteropolitanas e de diferentes estados brasileiros compareceram para contribuírem nas atividades do evento.

Outro importante evento ocorrido em Salvador foi o festival de contracultura feminista Vulva La Vida - necessariamente feministas, necessariamente inconvenientes -, realizado de 19 a 23 janeiro de 2011 e organizado por uma rede de coletivos e de garotas que se colocam contra o que é chamado "feminino" na sociedade. O festival reuniu jovens de diversos estados brasileiros, em maior parte adeptas ao estilo rock da contracultura feminista, estando também presentes as hip hoppers. Já não era mais período

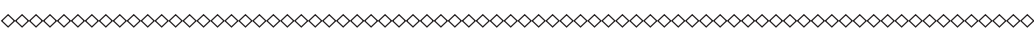

40 Endereço eletrônico do blog do curso: <http://www.cursobgirls.blogspot.com/>.

41 O Fundo Angela Borba de Recursos para Mulheres foi criado em agosto de 2000, a partir do Seminário internacional Mulheres, responsabilidade social e recursos financeiros, ocorrido no Rio de Janeiro para dar apoio a projetos brasileiros. É o primeiro fundo de investimento social brasileiro que direciona recursos exclusivamente para organizações de mulheres, sendo um exercício de captação e distribuição de recursos para atividades de investimento social na promoção e defesa dos direitos humanos das mulheres. Informações disponíveis em: <http:// pt.wiserearth.org/organization/view/090cc8836f45c0db26e306213ad2409a>. 
de trabalho de campo, mas ocorreu o acompanhamento da oficina de hip-hop com os elementos do break e do rap inseridos nas atividades do evento.

Em sua programação, o festival contou com exibições de filmes temáticos sobre mulheres e sexualidades, bate-papo sobre a bicicleta como meio de transporte, além de várias oficinas direcionadas exclusivamente para mulheres com os temas mais diversos, como vegetarianismo e alimentação vegana, moda e estética, feminismo e pornografia, wendo (luta de defesa feminina) e duas oficinas específicas envolvendo elementos do hip-hop. ${ }^{42}$

A oficina de dança de rua e de rap foram as primeiras, e ocorreram no dia 20, no turno da tarde, ministradas pela rapper e $b$-girl Negramone com a presença da também rapper e $b$-girl Carla Kaianapaz, também djeia, pois ficou responsável pelo beat box,,$^{43}$ conforme registrei nas minhas notas de campo:

No salão sem cadeiras que reunia as jovens participantes da oficina de rap e break, mulheres de diferentes vertentes poderiam ser identificadas por estilos musicais. Havia roqueiras com suas roupas rasgadas com blusas de banda, havia metaleiras que usavam roupas pretas e cabelos longos, mulheres de cabelo curto, corte moicano e até carecas, - estas eram as punks que exibiam maquiagens fortes, piercings e tatuagens.

A proposta do festival era reunir mulheres da contracultura, e essas jovens, muitas que não gostavam de hip-hop, algumas que não conheciam, ou que até ouviam um pouco de rap, estavam

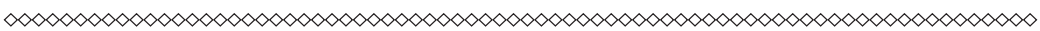

42 A oficina de graffiti e arte urbana ocorreu no dia 21, pela manhã, na sede da "Cozinha vegan" localizada no Pelourinho. Essa atividade teve continuidade no final da tarde, com o graffiti em bairros da cidade, e foi ministrada pela grafiteira Kátia, também conhecida por Sista K.

43 Beat box é o som produzido na boca, sem o uso de equipamentos musicais, produzindo a batida do rap, o qual a djeia ou rapper faz como base para que outra pessoa(s) cante(m), rimando em cima da batida. Beat box é apresentado por "bate lata" no trabalho sobre rap feminino em Campinas, de Mariana Semões de Lima (2005), porém, nesse caso, as rappers não faziam som com sua própria boca, mas "batiam com as mãos em uma lata". 
nessa oficina se abrindo para o hip-hop instigador de críticas vorazes a partir do rap, inicialmente, e, posteriormente, ao break.

Negramone começou a oficina falando um pouco sobre a história do hip-hop e de seus elementos, e depois mostrou como se organiza a métrica de uma rima, pedindo que Carla marcasse o beat da música. Depois a turma se dividiu em grupo para que produzissem sua própria música e letra de rap. O resultado foi um clima descontraído, produzindo mensagens de protesto em torno da liberdade do corpo das mulheres e a chance de muitas mulheres se permitirem ao envolvimento com o rap, especialmente para jovens que nem desse estilo gostavam.

No segundo momento, ao som de suas próprias músicas, cantadas pelo grupo que compôs e pelo restante da turma, as jovens fizeram uma roda de break que permitiu as formas mais variadas de dança apresentadas uma por uma no centro do círculo. (Diário de campo, Salvador, 20 jan. 2011)

Eventos como esses citados acima ajudam a contextualizar a discussão acerca das mulheres no movimento Hip-hop e sua percepção sobre o que é "coisa de menina" neste. Essa questão foi diretamente tratada pelas hip hoppers no Seminário Lugar de mulher é também no hip-hop, e será foco de atenção a seguir, como um espaço especial de observação das expressões das convenções de gênero a partir da militância das hip hoppers.

O trabalho de campo contou com o acompanhamento integral da realização do seminário citado acima, que durou dois dias, e teve início no sábado, dia 14 de agosto de 2010, reunindo aproximadamente 40 pessoas, em sua maioria mulheres negras e jovens, mas também crianças e homens. Esse evento foi realizado após duas remarcações de datas anteriores, até que finalmente se confirmou sua realização, não sendo divulgado o motivo de seus adiamentos.

Em meio à plateia do evento, pode-se sentir um clima de curiosidade, sobretudo das jovens que ali chegaram. Entre as 
perguntas curiosas envolvendo o cenário hip-hop, destacou-se: o que iria mesmo acontecer naquele espaço? Seria um show? Uma festa? Uma aula? Uma mesa de debate sobre algum tema relacionado ao hip-hop?

Não se sabia como seria a organização daquele espaço promovido pelas hip hoppers. Elas estavam interessadas em conversar, discutir temas diversos acerca da presença das mulheres no hip-hop, em apresentar algumas personalidades com trabalhos em torno dos quatro elementos do hip-hop e que compartilhassem experiências em projetos vinculados às suas artes e militância.

Vale ressaltar que a presença dos homens - em minoria dessa vez, diante do caráter de um encontro específico do movimento de mulheres, mas de abertura para participação dos homens foi priorizada nas mesas de debate com a presença de parceiros convidados a relatar sua experiência de colaboração com os trabalhos e ações das mulheres no movimento. Em especial, as mesas do Seminário contaram com a presença de homens e DJs do cenário do movimento Hip-hop de Salvador. O primeiro deles, o DJ Bandido, com marcada contribuição por incentivos à produção feminina no rap e, o segundo, DJ Jarrão, que compõe o grupo de rap chamado Audácia, ex-Neuróticas, composto até então apenas por mulheres. Também havia reduzida presença de homens na plateia.

O Seminário teve início com uma fala das rappers, Cintia Neurótica, da banda Audácia, sobre a importância do evento e sobre o Núcleo que o produzia. A rapper Mara Asantawaa também deu as boas-vindas às participantes e colocou sua preocupação sobre as dificuldades das mulheres se articularem no hip-hop, mesmo essas tendo relevante participação em determinados elementos. Dado por aberto o seminário, as rappers apresentaram de forma entusiasmada a programação. 
A mesa de abertura teve como tema "Um breve histórico sobre a atuação da mulher no Hip-hop baiano e o cenário atual”, e foi composta pelas rappers Dina Lopes (ex-Último Trem) e Simone Gonçalves (Negramone), da banda Munegrale. A contribuição das rappers trouxe o relato de suas experiências femininas no hip-hop. Elas traçaram um breve histórico do movimento de mulheres dentro do movimento Hip-hop baiano, ao destacar em, sobretudo, as transformações por que passaram mulheres após entrar no Movimento.

Nas falas de ambas as palestrantes estavam presentes símbolos de força, coragem e poder que identificavam as convenções de gênero acerca do modelo de feminilidade que se destacava em diversas expressões, a exemplo da atitude de subir no palco, mostrar sua música, afirmar sua identidade de mulher, negra, lésbica e outras. Entre elas, foram destacadas questões em torno do contato e sua inserção no hip-hop, e o envolvimento com seus elementos, sob críticas que se aportavam a um modelo masculino de atuação, como vestir roupas folgadas, falar no estilo "malandro", cantar com uma mão no microfone e a outra como que pegando no pênis. ${ }^{44}$

O hip-hop tem aspectos que o caracterizam como um movimento masculinista diante da majoritária presença de homens que expõem determinados símbolos, modos de comportamento, linguagens e entre outros aspectos que são reconhecidos pelo estilo (modelo) "hip-hop de ser".

Dina, uma das primeiras rappers a cantar na capital baiana quando integrante da banda Último trem, durante os anos de 1996 a 2003, foi questionada sobre a inserção das mulheres no Movimento e nos elementos do hip-hop e sobre a relação para com os homens, afirmando que:

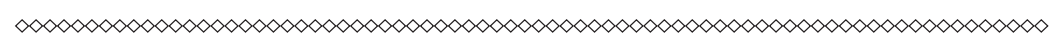

44 As hip hoppers fazem imitações, como sátiras, mostrando a forma de cantar de muitos rappers. Elas brincam "Será que têm medo de sair?" 
É uma relação conflituosa, porque é uma relação de ocupar espaços, porque a partir do momento em que os homens já estão culturalmente inseridos, que eles têm mais poder do que nós mulheres, é uma relação difusa mesmo, você tem que chegar e dizer para ele, 'não é assim! Esse espaço é nosso!'.

A fala de Dina expõe a percepção acerca das expressões das convenções de gênero no hip-hop. Para tanto, é a partir das falas das hip hoppers que se destacam as experiências das mulheres em seu envolvimento com os elementos do hip-hop e seu diálogo com as convenções de gênero no Movimento.

Nesse sentido, é possível elencar algumas questões que podem orientar a compreensão em torno desse debate. Quais são as convenções de gênero identificadas dentro do hip-hop, que se diz um movimento contestatório? Como se constituem os modelos de feminilidade e masculinidade no hip-hop? Como são expressas essas regras e limites para que se distinga o que pertence ou não ao masculino e ao feminino? Para essas e mais algumas questões que surgiram no intuito de identificar as convenções de gênero no hip-hop, foram consultadas algumas hip hoppers soteropolitanas que compartilharam experiências em torno de sua inserção e permanência no movimento.

A partir das particularidades do campo são destacados dados fundamentais que auxiliam na compreensão do olhar sob a militância das mulheres no campo do movimento social Hip-hop em Salvador. São casos selecionados que expressam as convenções de gênero encontradas e que aguçam a percepção de como essa militância feminina transforma ou reforça essas convenções de gênero nesse campo.

Das experiências compartilhadas pelas mulheres hip hoppers, foram selecionadas quatro relacionadas aos elementos rap, grafite, break e militância. 


\section{Uma rapper: salto alto $X$ tênis, minissaia $X$ calça larga}

Como estilo musical do hip-hop, o rap é o elemento de maior destaque entre suas expressões, criado a partir de letras politizadas sob diferentes estilos de batidas, descrevendo e envolvendo o cenário cultural e político por onde passa. A sigla RAP significa a junção do "ritmo e poesia" (Rhythm and Poetry - expressão em inglês) e é muitas vezes improvisado por DJs (Disk Jóqueis) e MCs (Mestre de cerimônia).

Esse estilo musical nasceu em Nova York sob influências de diversos estilos, entre eles, soul, jazz, blues e funk, além de outras novidades oriundas da Jamaica. O que esses estilos têm em comum é que todos são expressões da musicalidade negra. (SOUZA, 1998) Entretanto, Sansone (1997) destaca que eles não podem ser entendidos como homogeneizados e massificados, pois têm diferentes e específicos registros de tempo e espaço. Porém, o autor identifica os estilos reggae, funk e o hip-hop como retrato das juventudes globais, criados pela mídia e reconhecidos pelas ciências sociais.

As expressões desses gêneros musicais foram relevantes para a politização acerca da identidade negra, de imigrantes e de pobres, e instrumentos de problematização das condições de vida da população negra em especial, e também de outros grupos pelo mundo. Segundo Wivian Weller (2005), o hip-hop surge com uma concepção de articulação e combate contra o racismo e o preconceito.

Existem vários tipos de rap, em sua maioria inicialmente difundidos nos Estados Unidos, e posteriormente expandidos pelo mundo, sendo que entre eles pode ser citado o rap gângster, vinculado à criminalidade e do qual o movimento se coloca de forma 
contrária. No Brasil, é mais comum o rap militante, de discusso engajado, entrada no movimento social Hip- hop.

Quem canta rap é rapper e esses são homens ou mulheres. Ambos os sexos têm usado essa arte como uma forma de falarem sobre si mesmos e sobre suas inquietações. Entretanto, o espaço do rap tem se configurado pela sua masculinização, um tanto intimista diante de eventuais empurrões, brigas e rodas de bate- cabeça. Assim, como mostrou a pesquisa de Fernanda Noronha (2007) no ambiente do movimento Hip-hop paulista nesta primeira década do século, o cenário soteropolitano compartilha a reduzida presença feminina nos shows de rap, estando as mulheres, em sua maioria, acompanhadas ou protegidas em grupinhos.

A presença das mulheres na plateia de shows de rap para a apresentação de uma rapper no palco pode ser conhecida através do aprofundamento da experiência de Dina como rapper. Sua atuação teve início no rap ao integrar a banda Último trem, quando era a única mulher a participar da sua formação. Ela relata sua vivência de mulher e rapper no movimento Hip-hop:

Tipo cantar rap, para você ser vista como mulher você tinha que se vestir como os homens, usar jeans, usar tênis. Eu particularmente não gosto de usar tênis, eu particularmente não gosto de usar calça folgada, coisa de homem, eu não gosto. Eu gosto de usar vestido, sainha, entendeu, então isso já era uma oportunidade, quando eu me vestia para cantar e eu ia de um salto alto, tinha questionamentos, tinham olhares.

Em sua fala na mesa de abertura do Seminário Lugar de mulher é no Hip-hop, Dina defendia a afirmação de aspectos que identificavam as mulheres que queriam cantar rap como mulheres, com seus adereços, que independente de suas orientações sexuais 
faziam parte do que as diferenciavam dos homens. Ela se coloca contra a convenção que imputa masculinização da atuação para o reconhecimento dessa arte feita por mulheres.

Dina conta que no primeiro momento de organização do movimento em Salvador, quando Posse Ori, as mulheres ainda não tinham muita crítica sobre sua condição de mulheres, e reproduziam um imaginário de que havia um modelo de ser rapper a ser obedecido, como condição para se obter reconhecimento de sua produção e performance artística. Esse modelo se aportava nas referências masculinas dos rappers estadunidenses, a exemplo de $2 \mathrm{PAC} .{ }^{45}$ Assim, os homens rappers, negros, apresentavam um estilo rapper e também hip hopper de ser por um estilo de vestir.

Foi esse estilo de vestir, hip hopper, que a rapper Dina contestou, por dialogar com uma das convenções de gênero acerca da masculinidade e também da feminilidade no hip-hop, em torno do imaginário de que ele e o rap são coisas de menino, de homem. É o que nos explica Souza (1998), quando descreve que o rap é um estilo musical associado à marginalidade, vindo do gueto e do negro, que encontra inspiração em meninos de rua, presidiários, times de basquete ou futebol (no caso brasileiro) que inspiram referências ao popular.

Esse modelo tradicional de como ser um rapper obedecia à perspectiva de masculinidade composta por itens imprescindíveis como calça folgadas, bonés, tênis grandes e coloridos, longas e folgadas blusas e camisetas, de preferência que exibissem determinadas marcas famosas, a exemplo de Adidas, Nike, Mizuno e outras de grande circulação internacional, e com referência ao "inglês", que remetesse ao hip-hop dos Estados Unidos. Realmente esse era o estilo promovido por rappers estadunidenses, divulgados especialmente em canais de televisão musicais, a exemplo da MTV

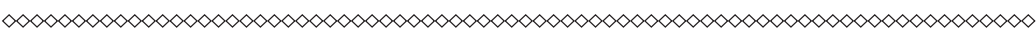
45 Famoso rapper estadunidense assassinado em sua comunidade por um integrante de uma gangue rival. (SOUZA, 1998) 
(Music Television) e dos grandes rappers divulgados na mídia comercial.

No hip-hop soteropolitano - e em geral -, é bastante comum encontrar jovens adeptos do estilo e da moda hip-hop estadunidense. Muitas vezes, a impressão sobre esses jovens é de uma incoerência, devido à realidade financeira da classe popular em que vivem em relação às marcas caras e exibição de etiquetas, mesmo que sejam peças falsificadas - sendo que alguns não são -, mas, sobretudo, pelo próprio clima quente da capital baiana em sua maior parte do ano.

Segundo os (as) militantes, isso ocorre porque muitos obedecem a uma lógica do hip-hop como produto da indústria cultural, bem distinto e afastado do que seria o hip-hop enquanto movimento social. Porém, enquanto alguns segmentos do hip-hop soteropolitano o reproduzem, outros têm uma crítica extrema sobre esse estilo.

Integrantes dos grupos pertencentes à Rede Aiyê Hip-Hop discutiam sobre as roupas de hip-hop estadunidenses usadas pelo hip hoppers soteropolitanos e defendiam o uso de sandálias de couro e chapéus de palha, a fim de resgatar a história dos contadores de história dos griôs africanos e dos repentistas nordestinos com suas rimas e críticas sociais, de forma sátira e cômica, ao embolarem ritmo e poesia, compartilhando a fórmula do rap e da embolada.

Como resposta a este estilo comercial, seus elementos eram adaptados ao clima quente local e à linguagem verbal e corporal do nordeste brasileiro, inclusive em suas letras e performances no rap. Como moda alternativa do hip-hop local, o casal de dançarinos de rua, Tina e Ananias, criam roupas para b-girls e b-boys, adaptando a prioridade de uma roupa leve e confortável para dançar ao estilo hip hopper soteropolitano. Tina descreveu a experiência da grife de hip-hop, que realizou desfiles no Pelourinho em atividades do movimento durante sua 
participação em uma das mesas do Seminário Coisa de Menina. Ela contou que as roupas de hip-hop eram caras e pouco acessíveis aos jovens, e que as peças por eles trabalhadas são encomendadas por preços acessíveis ao público-alvo. (Diário de campo, 2010)

A inserção das mulheres na arte musical do hip-hop, o rap - que chega a ser conhecido até por hip-hop -, provocou certa mudança no que vinha a ser estabelecido a um gênero específico, à medida que elas formataram uma espécie de diálogo entre símbolos masculinos e femininos em volta do cantar rap. Saias, minissaias, vestidos e blusas "de alcinha" compunham o figurino das rappers, que subiam no palco e rimavam sob a batida do DJ.

Sapatos de salto alto passaram a ocupar espaços antes exclusivos de tênis coloridos, de cano alto ou baixo. Algumas rappers não abriam mão de sua maquiagem, batom e rímel, adereços nos cabelos e no corpo como turbantes e brincos grandes, pulseiras e penteados que exploravam a beleza negra, a exemplo dos cabelos estilo black power e trançados das formas mais inusitadas. Elas sobem nos palcos demonstrando que o rap também é coisa de menina e tem estilo feminino de performance para cantar, rimar (compor) e interagir com a plateia.

Geralmente, os nomes das bandas e nomes artísticos e de guerra das rappers têm uma conotação de empoderamento, força e luta, a exemplo do nome da banda Áudácia Feminina e da rapper carioca Refem (Revolta Feminina), responsável pela produção do documentário O rap do batom. Refem, como é chamada no movimento, veio a Salvador para participar do Encontro Nacional de Juventude Negra, e articular junto às mulheres do hip-hop soteropolitano a exibição de lançamento deste vídeo em Salvador. De qualquer forma, ela deixou com o Núcleo de Mulheres uma cópia do documentário que trata dos desafios de uma rapper no Rio de Janeiro, a partir de sua própria biografia ao relatar seu contato com o movimento social hip-hop, as impressões de sua mãe para com o rap antes e depois de conhecer as 
produções musicais da filha, as novas perspectivas que o rap deu à sua vida, entre outras questões em torno da sexualidade, amizades e profissionalização. (Diário de campo, 2008)

Contudo, as oportunidades para as mulheres no rap soteropolitano são bastante limitadas diante de duas questões: a primeira, pelo próprio cenário musical da cidade, que desprivilegia o gênero musical rap em favor de uma indústria cultural que produz, sobretudo, estilos como a música baiana, axé e pagode, além de outros estilos mais comerciais, a exemplo do forró. Os espaços para a música rap já são restritos no cenário baiano, mesmo que aconteça numa cena alternativa exclusiva para esse estilo, a exemplo do Programa Evolução Hip-Hop na rádio pública, com uma programação voltada para produção e para o público do gênero musical rap. Esse programa foi resultado de uma articulação entre o Instituto de Rádio e Difusão do Estado da Bahia (IRDEB), juntamente com segmentos do movimento Hip-hop. Mesmo nessa programação, a presença das rappers soteropolitanas é tímida. ${ }^{46}$

Já a segunda questão está mesmo vinculada a gênero, para se pensar o espaço das mulheres no rap no meio específico hip-hop. Há uma espécie de controle e "autorização" para que as rappers apresentem suas produções como que em uma disputa, em um espaço predominantemente masculino, sendo, em especial, o palco e o microfone espaços de poder. Esse controle engloba o comportamento, as roupas e o acesso das rappers, muitas vezes sendo colocado pelos homens como uma espécie de proteção, e que implica inclusive em limites das oportunidades de trabalho profissional. (SILVA, 1995; MATSUNAGA, 2008; GOMES, 2008)

Atrelado à importância das referências femininas no rap, Vivian Quartuni conta sobre as raras oportunidades para a apresentação

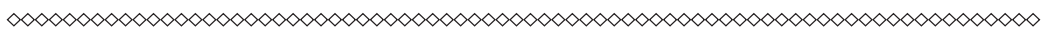

46 A presença das mulheres hip hoppers em geral, independente de um elemento específico, na própria articulação do programa, foi importante, mas temporária, especialmente no projeto, articulação e primeiros momentos. 
das mulheres nesse estilo na cidade. Espaços cada vez mais pontuais para o desenvolvimento desta arte musical do hip-hop pelas rappers,

Deixa eu pensar [risos]. Eu acho que ainda é pouco. Eu não falo nem na questão política, mas eu acho assim até em eventos, se a gente for contar quantos grupos femininos tocam numa noite? Eu só vi um show... onde é que foi?... que foi no Bairro da Paz... no São Caetano e no Bairro da paz, ${ }^{47}$ dois, aliás, que tinham três grupos de homens mistos e três grupos femininos. Então assim... e as meninas todas foram pro palco de saia, a mesa toda do debate foram mulheres que tavam tomando conta. Então assim, são poucos, mas só que essas poucas deixam marcas e deixam história, que depois até... é... até depois as outras pessoas que não acreditaram que as coisas acontecia, porque são mulheres que estão fazendo, é... diz que a...coisa foi bem feita e parabeniza. Acho que são poucas, mas deixam marca, como o encontro de gênero, são poucas, mas deixam marcas e deixam saudade.

Sendo essa uma questão de importância para as hip hoppers, a programação do Seminário Lugar de mulher também é no Hip-Hop priorizou essa discussão e problematizou os desafios das rappers para produzir seus trabalhos. Para compor essa mesa de debate temática, foi convidado um homem, um DJ, o DJ Bandido. Ele é uma personalidade que tem se destacado por seus trabalhos

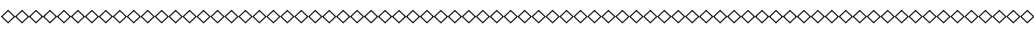

470 evento de Hip-Hop que teve como tema "Hip Hop contra a homofobia" aconteceu em 2007, no Bairro da Paz, e foi liderado pelas mulheres, que estavam não apenas nos espaços das mesas de debate, mas também no palco, contando com a participação de cerca de três bandas de rap compostas exclusivamente por mulheres, sendo duas delas baianas e uma do Piauí. 0 evento ocorreu sob rigoroso esquema de negociação com a escola municipal do bairro e com o grupo "Clã Nordestino", importante segmento do Hip-Hop local e responsável pela articulação dessa produção, que aconteceu na praça principal do bairro, reunindo um número grande de pessoas do local e de outros bairros, sobretudo, jovens. 
de discotecagem e pelo incentivo ao trabalho das rappers em Salvador.

DJ Bandido possui seu próprio estúdio, no bairro do Nordeste de Amaralina, e em inúmeras oportunidades apoiou a produção da rappers. Responsável por incentivar a gravação de um CD exclusivo de mulheres rappers de Salvador, e negociar com as rappers, ainda sem alcançar o resultado esperado, ele aponta como um dos principais problemas para fomentar esse trabalho o próprio comportamento das mulheres. Os registros das produções das rappers são tímidos.

Segundo Bandido, muitas delas desistem de participar da iniciativa porque o namorado disse que ela não devia rimar, ou mesmo que ela não seria uma boa rapper com presença de palco e com entonação para encarar um trabalho como esse. Nesse caso, ele se refere às rappers iniciantes no ramo, ainda inexperientes e em início de carreira. Entretanto, isso também acontece com as rappers de maior tempo no movimento e no próprio rap. São inúmeros os empecilhos que afastam as mulheres de simplesmente registrarem seus trabalhos no hip-hop, estando muito atrelados à questão de autoestima para se expor a críticas, problemas financeiros para dar continuidade a um projeto e, sobretudo, à falta de apoio dentro e fora do movimento Hip-hop.

Como um exemplo a essa fala do DJ Bandido, a rapper e pedagoga Paula Azeviche expõe alguns pontos importantes para pensar a situação do "ser mulher" no rap e no hip-hop. Ela levanta problemáticas que explicam questões específicas compartilhadas pelas mulheres diante de um contexto que compromete sua participação dos espaços e atividades públicas na sociedade e no movimento social.

A primeira delas está vinculada à questão da referenciada participação de outras mulheres no cenário do rap, sendo essa questão recorrente nas discussões entre mulheres hip hoppers, 
e compartilhadas em outros segmentos do movimento social e nos espaços políticos. Como exemplo, Paula cita sua própria experiência e suas motivações para começar a cantar rap a partir da amiga Sílvia, rapper e fundadora de uma das primeiras bandas de rap exclusivamente composta por mulheres, banda chamada de Hera Negra.

Ai um dia Sílvia se retou e começou a rimar, e começou a mostrar os rap, começou a mostrar... dizer que tinha várias letras e a menina apareceu com um monte de letras. E eu achei que podia fazer rap também, quer dizer eu sou bem lenta pra fazer rap. Mas Sílvia foi uma grande inspiração, é uma mulher que depois de Dina D, aí quando eu olho pra trás, é importante que hoje tenha tantas outras mulheres fazendo rap.

Abaixo, segue o registro de um dos shows da banda Hera Negra, em uma de suas formações, no momento, as rappers Negramone, Sílvia e Lica. A banda atuou durante os primeiros anos do hip-hop em Salvador e foi extinta após diversas formações, e não tem registros de suas produções disponíveis para acesso, sendo um dos exemplos no qual se adequa a preocupações expostas acima sobre os não registros das rappers.

Paula e Bandido apontaram a mesma preocupação com relação às dificuldades de permanência e de continuidade dos trabalhos das mulheres no movimento e na produção de suas letras e performances. De acordo com os relatos das experiências das mulheres, é possível perceber como se configuram as características que compõem as convenções de gênero em torno da feminilidade, as quais as mulheres estão submetidas.

Paula usa alguns exemplos para pensar sobre a ausência e permanência das mulheres no movimento, inclusive acerca do tipo de permanência e os principais motivos que afastam as mulheres 
desse meio, a partir do relato de sua própria experiência como a única mulher em uma banda de rap, com maioria de homens. Segundo a rapper, as mulheres

[...] não estão próximas do movimento assim, quanto eu esperava e a gente sabe que é muito difícil. É muito difícil essa permanência, porque a mulher, ela exerce todas as funções na sociedade, a gente está na pirâmide na base quer o homem queria ou não. A gente tem que ser mãe, tem que ser filha, tem que ser mulher, tem que ser dona de casa, tem que trabalhar fora, tem que ter todos os direitos garantidos, tem que pagar as contas, tem que... Sei lá, fazer tudo [...] Até na 'Simples Rap'ortagem', eu sempre tive o papel de fazer a produção da banda, de cuidar daqueles homens todos, de saber 'você tá onde?'. Até hoje é a mesma preocupação e hoje a gente tenta passar todas as atividades com o produtor, mas mesmo assim. Em oito anos de Simples sempre foi assim. E a gente sabe que a gente entra no hip-hop quer fazer as coisas, mas o que acontece, a gente encontra o movimento desestruturado, a gente quer organizar, a gente quer arrumar a casa, a gente que deixa tudo limpo e aí vai. Os processos vão engolindo a gente, engolindo, engolindo, quando a gente vê... Uma vez alguém me disse assim que eu tava lamentando a saída de Dina, que Dina parece que saiu do movimento de vez assim. Lógico que ela não vai sair, porque quem conhece ela sabe que ela é a história do movimento. Mas que tava lamentando a ausência de Dina, e alguém me disse assim: 'Dina já é mulher, Dina tem filha, Dina tem que sustentar a casa'. Eu digo: 'Poxa, será que a gente começa tudo isso, sem acreditar que a gente possa algum dia sustentar a nossa casa do hip-hop'. Ela tem uma filha grande, eu acho que ela teve filho muito cedo, teve a filha muito cedo. Enfim, a gente passa por 
todas essas barras, tem que ser abandonada, tem que ser a traída, tem que ser a que realiza os desejos do marido, tem que ser tudo e ainda fazer hip-hop [risos]. Difícil! Do marido, da mulher, 'né', sempre realizando o desejo de todo mundo e ainda ser do hip- hop. E ai [risos].

É interessante notar que, mesmo com determinadas funções de administração da agenda artística atreladas às atribuições do produtor, a rapper que esteve até então como única mulher na banda assumiu a responsbilidade de "cuidar dos homens" desta. Além de cantar, ela também resolvia questões gerenciais referidas ao trabalho de "cuidar" de seus colegas de trabalho, o que reforça as convenções de gênero tradicionais que vinculam essas características ao feminino. A seguir, é direcionada a atenção para como essas convenções de gênero do feminino e do masculino se expressam no grafite.

\section{Maria latinha não, grafiteira!}

Como já mencionado, o grafite foi um dos dois primeiros elementos do hip-hop, juntamente com o break, e consiste nas expressões das artes plásticas do hip-hop por meio de pinturas e desenhos exibidos nos muros da cidade.

A experiência das mulheres no grafite também não se diferencia das rappers. A grafiteira Mônica Reis palestrou em uma das mesas do Seminário Lugar de Mulher é no Hip-Hop. Exibindo unhas coloridas cor-de-rosa choque, que de longe podiam ser vistas, cabelos pintados de tons avermelhados contrastando com sua pele escura, chamou atenção não apenas pela aparência, mas especialmente pela sua fala crítica ao relatar a experiência das mulheres no grafite em Salvador. 
Vale ressaltar, como retrospectiva do movimento de mulheres hip hoppers, que a presença de grafiteiras no hip-hop soteropolitano é relativamente recente, já que essas têm adentrado no movimento a partir dos últimos cinco anos, e, diante dos registros, não participaram das atividades dos encontros de gênero e hip-hop, ou mesmo dos núcleos de mulheres de posses mistas. Esse primeiro período do hip-hop em Salvador, chamado de primeira geração do movimento (FREIRE, 2010), tinha características bastante vinculadas aos diversos segmentos do movimento Negro, inclusive ao próprio Movimento Negro Unificado (MNU) e outros movimentos sociais, a exemplo do movimento Feminista e Movimento de Mulheres Negras, entre outros.

Essa vinculação é que pode justificar o próprio título dos "Encontros de gênero e Hip-Hop", realizados entre 2003 e 2005, quando esta discussão em torno do termo "gênero" não era difundida na sociedade, mas já fazia parte da gramática da militância do movimento de mulheres no hip-hop soteropolitano e baiano, pois os encontros foram regionais e estaduais, nos quais se distinguiam do movimento de outros estados do Nordeste e do Brasil.

Esse primeiro período do movimento de mulheres já apontava uma perspectiva feminista devido às suas pautas vinculadas à preocupação com direitos e políticas públicas para mulheres, mais do que apenas um interesse para com a cultura hip-hop e seus elementos.

O exemplo de Mônica, que se insere no hip-hop em um segundo momento do movimento, é um relato interessante, pois demonstra questões que envolvem a inserção das grafiteiras nas artes plásticas do movimento. A arte de grafitar tem como ferramenta uma lata de spray, juntamente com muita disposição para enfrentar sol, chuva, grandes caminhadas e negociações à procura de espaços e oportunidades para pintar, além de inspiração para 
o trabalho. Entretanto, para as grafiteiras, os desafios são maiores do que esses, como relata Mônica:

Desde que eu comecei a grafitar e a participar de encontros, essas coisas assim, o que eu ouço falar de meninos falando sobre mulheres, fala de mulher que quer ser grafiteira, chama de 'Maria Latinha', mulher no hip-hop 'Maria Microfone', cada um, eles são apelidos para as mulheres, então acha que não é capaz, e faz porque sempre tem que ter um homem, ou tá fazendo porque acha que gosta de alguém, ou quer pegar alguém, então a mulher é muito desvalorizada, muito desrespeitadas por ser mulher em si entendeu? Então para mim essa é a principal dificuldade que nós temos no meio do hip-hop: apelidadas, esculhambadas, acham que somos incapazes, é copiar, é querer fazer uma coisa que a gente não quer, que isso é para homem, e isso não é para mulher, como antigamente, sabe inventa onda, e hoje a gente sabe que lugar de mulher também é no hip-hop, lugar de mulher também é no grafite, é lugar de mulher é lugar de mulher, então para mim é isso.

É interessante observar que as mulheres são geralmente apelidadas por "Maria algum objeto", relacionando o interesse das mulheres a algum objeto de valor estrangeiro ao seu universo de gênero. Os apelidos dados às mulheres no hip-hop relembram outros apelidos atribuídos a elas, a exemplo do "Maria gasolina", vinculando o interesse de mulheres a homens com carros, e também "Maria chuteira", para as mulheres que buscam relacionamentos com jogadores de futebol bem-sucedidos.

O que se pode apreender desse processo de desqualificação das práticas das hip hoppers é a forma como atendem às convenções sociais de gênero, que definem distintos repertórios, valores e símbolos para o feminino e para o masculino. Dessa forma, as 
grafiteiras, quando se apropriam de atributos masculinos - no caso, a latinha de spray -, trasgredindo as regras de gênero tacitamente estabelecidas, sofrem sanções do grupo em forma de desqualificação e desvalorização. Tais sanções instituem processos de produção de desigualdades e hierarquizações de gênero que recaem negativamente sobre o feminino.

A lata de spray, o microfone, o carro e a chuteira são hoje objetos acessados pelas mulheres, mas simbolicamente objetos do universo masculino. Nesse sentido, é curioso notar que não há uma versão para o masculino desse processo de nominação. Não há notícias de nenhum "João ou José tal objeto”, o que explícita a existência de universos de gênero delimitados, em que objetos como automóveis, chuteiras de futebol, microfones e, também, a lata de spray, são considerados "do masculino".

Grafite é coisa de menina? Como uma das poucas mulheres nessa arte do hip-hop, a grafiteira que participa há cinco anos do projeto Salvador grafita, ${ }^{48}$ ligado à Prefeitura de Salvador, se dedica ao desenvolvimento de imagens femininas - bonecas personalizadas - em seus grafites e já expôs seus trabalhos em países como Itália, além de registros em revistas europeias especializadas na área. Mesmo respondendo por esse currículo que foi construído no decorrer desses anos, o interesse está em como foi sua experiência, em especial, ao adentrar no espaço do grafite como uma mulher grafiteira em Salvador.

MÔNICA: Claro, senti, senti muito preconceito.

PESQUISADORA: Dos próprios grafiteiros?

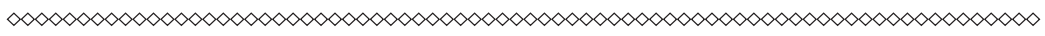

48 Projeto Salvador grafita, proposto e construído através do debate entre segmentos do movimento Hip-hop baiano e Prefeitura de Salvador. Esse projeto é administrado pela Secretaria Municipal de Educação e Cultura (Secult) e consiste na produção de grafiteiros e grafiteiras que trabalham com oficinas de grafite nas escolas públicas municipais, além de intervir com sua arte na estética urbana. (MORAES NETO, 2006) 
MÔNICA: Grafiteiro, companheiro, muito preconceito de dizer que meu trabalho não me qualificava no grafite, já fui colocada para pintar um muro pimenta ${ }^{49}$ você não consegue pintar; me dá um cantinho de muro, pequenininho, com uma parte de reboco sabe, você precisa ver aquele imenso jardim visto de fora, aquela coisa linda, em vez de incentivar, não, coloca aquela pessoa para pintar, mas se pudesse nem pintava no muro, assim como mulher, porque eles acham que o espaço é só deles entendeu, acham que só eles que tem que pintar, que só eles tem que fazer, e só eles que são capazes, e só eles que fazem as coisas mais bonitas, sabe? Acham que nós mulheres não somos capazes, então até hoje venho tentando mostrar que quem gosta é capaz de ter o seu espaço, sem precisar deles e fazer entendeu? Sofri muito preconceito, sim.

Mônica relembra uma experiência vivenciada junto ao seu marido - que também é grafiteiro e com quem tem duas crianças - que mostra o comportamento dos grafiteiros em relação às grafiteiras. Em seu relato, veremos como ela foi tratada pelos grafiteiros numa oportunidade de um trabalho de grafite coletivo:

Tem pouco tempo que meu marido foi para um grafite, foi convidado para um grafite, que ia ser um muro imenso. Chamaram ele, que chamou uns meninos, e ai eu perguntei pro meu marido: 'Por que não me chamou? Por que eu não pude participar?', 'Ah, eu não sei, porque disse que o muro já tava certo'. Isso não existe, é discriminação pô, é discriminação, sabe que eu também pinto, que eu tô dentro de casa, que eu também pinto, e sempre quando rola alguma coisa eu te chamo, para mim isso é discriminação entendeu? Eu acho assim, porque o grafite é mais para

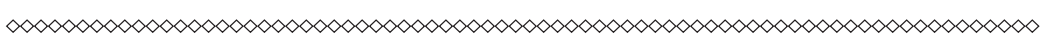
49 "Muro pimenta" é termo utilizado para um espaço em que é difícil para pintar. 
homem e pronto, entendeu? Mas se eu fizer o muro, e dá para todo mundo, pronto, o muro é pequeno, mesmo que dê para cada um colocar uma letrinha, um olho, mas dá para todo mundo fazer, tem um pouco de discriminação e essa parte eu não gosto, mas eu vou ter que lutar, eu estou sempre lutando para quebrar isso.

Mônica é questionada sobre como é ser mulher no grafite diante de suas experiências com diferentes vertentes do hip-hop. A grafiteira, que reafirma haver poucas mulheres no grafite e que fez uma enquete em sua página da rede social Orkut com a chamada "Quem disse que grafite não é coisa de mulher?”, respondeu-me que ser grafiteira:

É saber que lugar de mulher não é só na cozinha, não é só na panela, não lavando, não é cuidando de criança, que o lugar de mulher é também no meio do grafite, entendeu? Lugar de mulher também é no grafite, lugar de mulher também é pintando, e ser mulher é além de tudo é ser, é fazer, é chegar lá e meter a mão.

O caso de Mônica aponta para uma busca de transformação das convenções de gênero em torno da atuação das grafiteiras. Entretanto, Mônica afirma que tem encontrado muita resistência para a articulação das mulheres no grafite. Ela expõe a experiência de sua Crew, expressão que dá nome ao grupo de grafite (MATSUNAGA, 2008), que no seu caso é composto por outras duas grafiteiras de outros estados. Elas se comunicam pela internet e têm encontros eventuais, mas cada uma representa a crew em sua cidade e estado, e em oportunidades de viagens e eventos. Mônica relata ainda que em Salvador não consegue mobilizar grafiteiras para trabalhos coletivos, pois além de serem poucas mulheres envolvidas, não tem surgido interesse destas em grafites coletivos. Também cita os nomes de algumas grafiteiras que têm trabalhos 
reconhecidos na área, a exemplo das soteropolitanas Rebeca, Kátia e Lica, com as quais ela afirma que pintou muito pouco. ${ }^{50}$

Uma dessas oportunidades de pinturas coletivas entre mulheres, contando com a participação também de grafiteiros, aconteceu no III Encontro de grafiteiras (FREIRE, 2010), ocorrido em Salvador, em 2008. Esse evento, em especial, marca a segunda geração do movimento de mulheres hip hoppers soteropolitanas, por se diferenciar das características apresentas na primeira geração.

Esse encontro teve um caráter internacional, pois além de reunir representantes do grafite baiano e de vários estados brasileiros, também contou com a presença de grafiteiras de países da América do Sul. Um aspecto interessante dessa articulação é sua comunicação a partir dos espaços virtuais na internet, a qual possibilitou a realização de um encontro com essa dimensão, com o objetivo de uma troca de experiência entre as mulheres no campo do grafite por meio da criação de redes virtuais de ação.

Esse evento marcou a atuação de novos segmentos do hip-hop, tendo uma formatação e pautas bem distintas dos eventos organizados por mulheres hip hoppers da primeira geração do movimento baiano, atuante nos anos anteriores, que demarcavam uma articulação profunda entre demandas vinculadas à questão de gênero, raça, classe e a própria forma de identidade militante do hip-hop, além do intrínseco contato e participação de outros movimentos sociais, especialmente negros e feministas. O evento em questão assumiu uma articulação de maior caráter jovem e de mulheres, sem apresentar fortes tensões em relação à classe e posicionamentos de afirmação feministas.

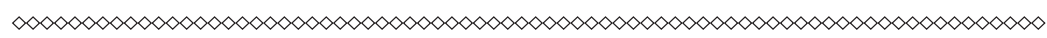

50 Algumas grafiteiras assumem o nome de Sista, uma referência adaptada pelo hip-hop para o termo sister, irmã em inglês, juntamente com a primeira letra de seu nome próprio, a exemplo de Sista K, a grafiteira Kátia. Vale ressaltar que Sister K, juntamente com outras grafiteiras soteropolitanas, foi uma das responsáveis por organizar o III Encontro de grafiteiras em 2008, e a Marcha das vadias (protesto feminista mundial contra a conivência à violência sexual contra as mulheres) ocorrida em Salvador, no dia 02 de julho de 2011. 
Talvez essa explicação de conjuntura possa dar subsídios para o entendimento do contexto de organização das grafiteiras, já que, segundo Mônica, há uma espécie de resistência para a organização das mulheres nessa arte. O relato da grafiteira é praticamente um desabafo, no qual aponta uma possível justificativa para esse cenário: a desunião entre as mulheres, tendo como principal interesse relacionamento íntimos - sexuais e afetivos com grafiteiros:

Muito o que eu vejo hoje são mulheres para quem grafiteiro é troféu, elas não procuram se unir, eu acho também muita falta de união, de chegar. Tem grafiteira que tá no meu Orkut, mas sequer ela fala 'Oi, tudo bem, tá pintando, tá pintando muito por aí?' Sequer dá resposta. Tudo bem, não tem necessidade disso, eu sou grafiteira, ela também é, eu acho que é por educação que eu tenho que falar dar um oi para pessoa. Às vezes eu chamo para pintar, tem gente que não vai, eu não sei que é porque tem gente que tem intriga com meu marido, intriga com minha crew, ou um pessoal meu, eu fico besta, muita má vontade para pintar, porque os meninos querem, conseguem se reunir para pintar? As meninas não podem fazer isso? Eu tenho cinco anos de grafite, e se eu pintei com as meninas de Salvador aqui foi pouco, pouquíssimo, e faço a maior questão da gente pintar, porque a gente tem que se unir, a gente tem que acabar com isso, o crew, crew, beleza, grafite é grafite, vamos se juntar, vamos pintar.

A justificativa utilizada por Mônica para a resistência à organização ou mesmo as pontuais ações entre grafiteiras, o "grafiteiro troféu", reproduz as normas tácitas de gênero de que há a necessidade de autorização e legitimação do masculino para a que o feminino se aproprie de atributos de seu universo. Nesse processo ambivalente de reforço das convenções e transgressões das 
regras, ao se apropriarem de um atributo e elementos do universo masculino, as grafiteiras desafiam essas mesmas convenções.

Interessa aportar como essa relação de ambivalência e de desafio aparece na produção artística da grafiteira. O grafite de Mônica, exposto na Avenida Carlos Gomes, no centro da cidade, traduz esta sua inquietação em relação ao mundo do grafite, sendo seu trabalho alvo de muitas críticas de diversos segmentos do movimento, a partir da representação das mulheres nos grafites em condições minimalistas e subjugadas, como mostram as fotos.

Figura 2 - Grafite de Mônica Reis na Avenida Carlos Gomes - Centro da cidade

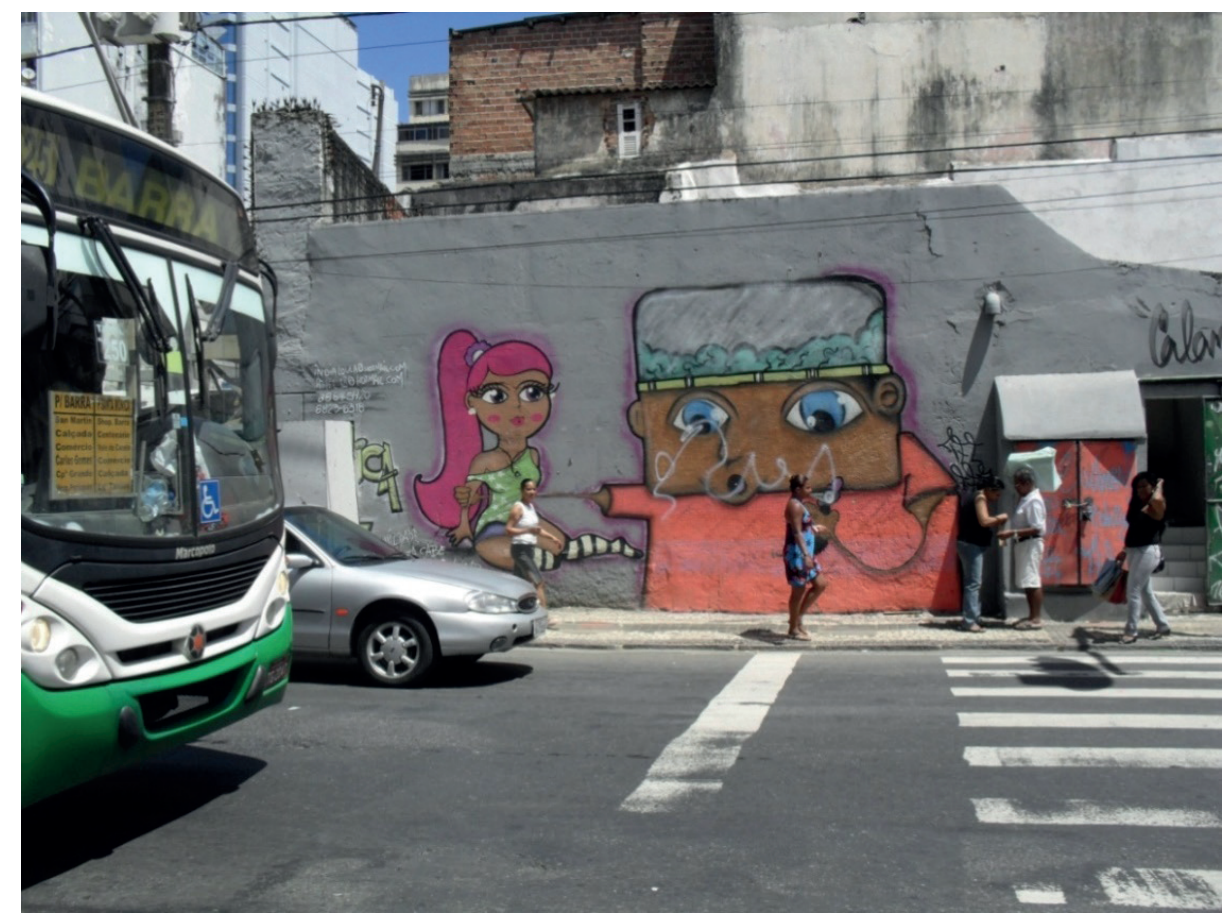

Fonte: produzido pela autora. 
Figuras 3 e 4 - Detalhes de grafite de Mônica Reis na Avenida Carlos Gomes - Centro da cidade

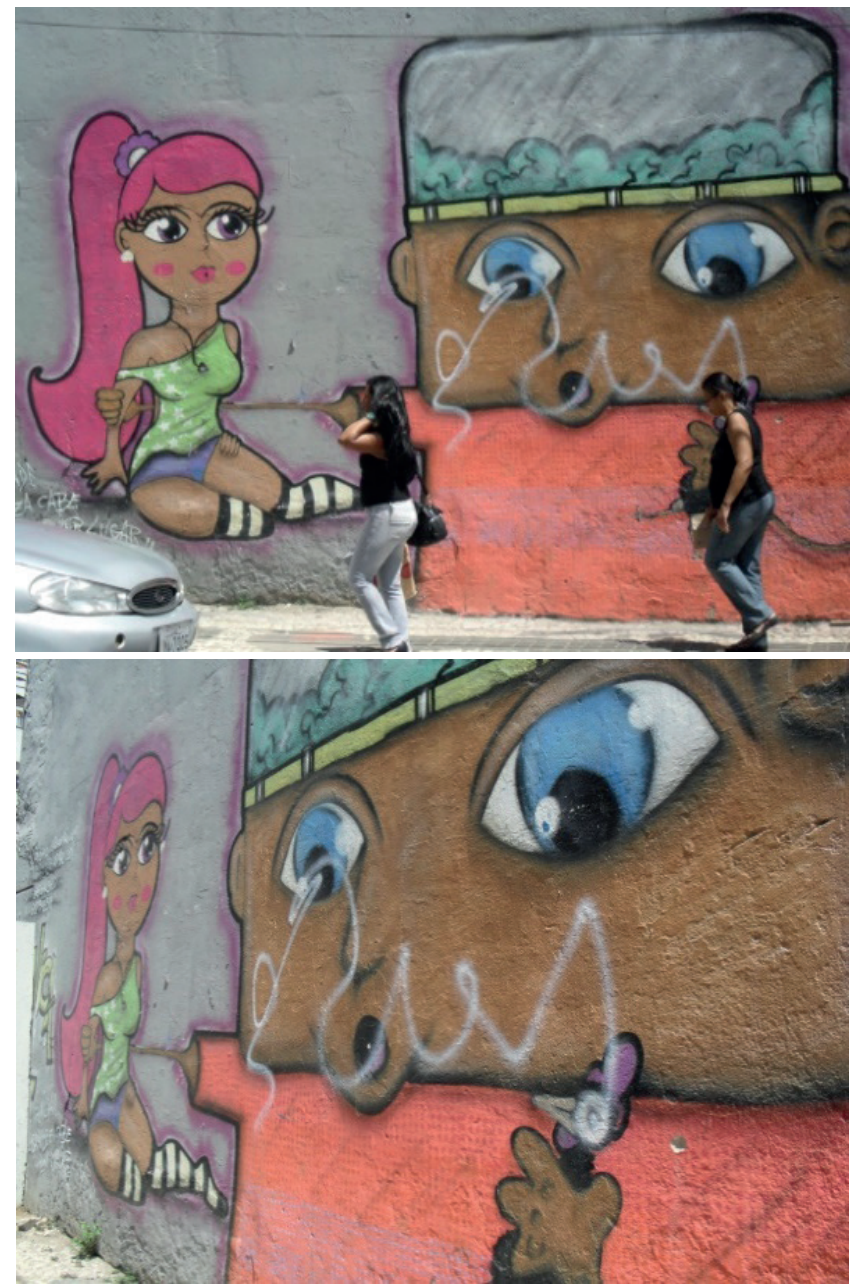

Fonte: produzido pela autora (2010).

O grafite de Mônica exibe uma pequena menina grafitada sentada no chão, aprisionada nas mãos de um grande menino, maior do que ela em força e tamanho. Na outra mão do menino, feito por um grafiteiro - há duas assinaturas no muro, o que parece ter sido um trabalho em dupla de um grafiteiro e uma grafiteira -, há um 
pássaro também aprisionado, transmitindo e reforçando a ideia de força e fragilidade das próprias dimensões dos desenhos.

O próximo tópico apresenta como essas convenções de gênero do feminino e do masculino se expressam no elemento break.

\section{Aula de break com uma mulher? Relatos da única b-girl da comunidade}

Entre as primeiras linguagens do hip-hop surgiu o break, a dança de rua também conhecida por street dance, que se expressa em diferentes estilos, entre eles, o poping, o breaking e outros. O break é responsável pela linguagem corporal do movimento, que traz consigo passos e gestos tomados de uma conotação de irreverência e de protesto, como nos outros elementos do hip-hop.

Embora o break seja a dança do hip-hop, não é exatamente dançada por rappers, grafiteiras e grafiteiros, ou mesmo pelo DJs ou djeias. Quem dança break são b-girls e b-boys, sendo a letra "b" abreviação da palavra break. Break significa "quebra" em inglês, que segundo autoras(es) e pessoas do movimento simboliza os corpos quebrados e mutilados dos soldados como protesto à Guerra do Vietnã ${ }^{11}$ (SOUZA, 1998), e também a situação de marginalidade e descaso, em especial em relação à saúde e moradia, vivenciada pela população negra e imigrantes nos Estados Unidos.

Para executar os movimentos dessa dança, $b$-girls e $b$-boys precisam de bastante força física, habilidade e coragem para ousar a realização de seus passos, pois esses reúnem diferentes danças e artes marciais, e são compostos por saltos em diversos níveis, coreografias e improvisação, a exemplo de floreios da capoeira que podem ser reconhecidos na adaptação ao break realizado no

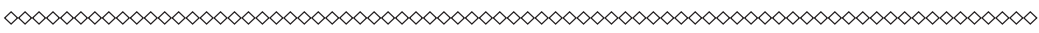

51 Em relatos de militantes e em suas versões sobre a Guerra do Vietnã, jovens negros foram colocados como linha de frente nos combates contra os vietnamitas. 
Brasil $^{52}$ e na Bahia. Isso pode ser explicado devido ao break compor uma série de passos e movimentações, mas que permite a inclusão de cultura corporal local como a capoeira, dança afro e até samba.

É possível encontrar apresentações do break em espaços públicos, como em praças da cidade e também na frente do palco em shows de rap e discotecagem em bailes black. São comumente reconhecidas entre jovens na cidade por roda de break, e reúnem transeuntes que aplaudem como torcidas as sequências de apresentações individuais e até coletivas de contagiante vibração ao som das batidas de um rap bem dançante e muitas mixagens.

Em sua maioria de b-boys, quanto maior o grau de dificuldade e ousadia do movimento, maior exigência de esforço físico, a interpretação do dançarino ou dançarina, e sua interação com o público, maior é a reação da plateia. Essa dança envolve um trabalho corporal praticamente ou próximo a um formato atlético. É o que acontece na roda de break que ocorria regularmente no Pelourinho, ${ }^{53}$ às terças-feiras.

Para conhecer experiências que contenham características simbólicas investigadas nas convenções de gênero no break foram acompanhadas atividades específicas com o break e entrevistadas algumas $b$-girls que desenvolvem a arte da dança de rua no movimento Hip-hop.

Entretanto, o número de $b$-girls é bastante reduzido se comparado com o número de $b$-boys. Esse cenário mais uma vez me remeteu ao artigo "Onde estão as b-girls?", em que Noronha (2007) apresenta a mudança de curso de sua pesquisa diante da falta de representações femininas nesse elemento do hip-hop. Não foi

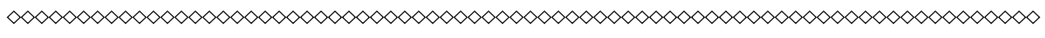

52 Esse aspecto de envolvimento da capoeira com o break também foi encontrado na pesquisa sobre hip-hop em Florianópolis (SOUZA, 1998), o que aponta a inclusão ou mesmo o diálogo dos passos clássicos do break com um aspecto da cultura brasileira, no caso a capoeira, que une dança e luta em sua composição.

53 Centro Histórico e Cultural Pelourinho localizado na parte alta da cidade de Salvador, bastante frequentado pela população soteropolitana e por turistas. 
o caso de Salvador, pois as b-girls, mesmo em um número menor, demonstram dominar a prática dos estilos de break dancing ao realizarem exercícios de alto grau de dificuldade, como malabarismos e contorcionismos, se apresentando não apenas na roda de break no Pelourinho - onde treinam junto com os b-boys -, mas também inseridas em grupos de dança de rua; além disso, competem em campeonatos e ministram atividades educacionais como aulas e cursos de break para juventude, a exemplo do citado curso de formação de $b$-girls.

Figura 5 - Aula do Curso de formação de b-girls (CEAO, 2008)

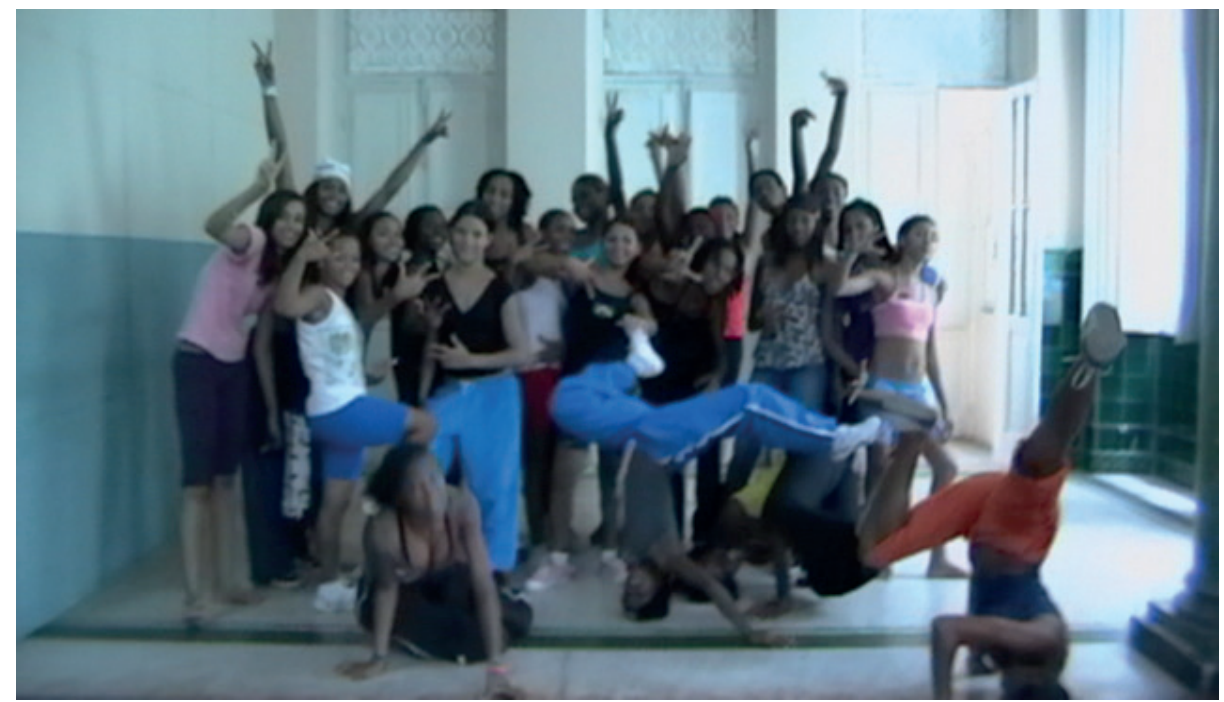

Fonte: produzido pela autora.

A experiência da $b$-girl Priscila Nayala - como professora de dança de rua - ao dar aulas práticas de break em sua comunidade é exemplar para compreendermos as convenções de gênero e a produção de desigualdades no hip-hop, a partir do elemento break. O principal empecilho em torno da ação da $b$-girl estava na noção de que hip-hop não seria coisa de menina, e que as pessoas com as 
quais ela se relacionam, familiares e amigos, não entenderiam sua relação de envolvimento com esse movimento.

PRISCILA: Muitas, principalmente do preconceito, que acham que a dança de break, acham que o hip-hop é pra menino e não pra menina, ainda existe isso, ainda existe este preconceito e eu sofro bastante com isso, inclusive dentro de casa. A minha mãe que deveria me apoiar é a primeira, minha mãe é a primeira a falar. [...] Sabe, ela não conversa mais sobre isso, não, aliás, quando, às vezes ela reclama, ela fala assim: 'ah, Priscila, ô como você está ficando toda musculosa, você está ridícula, você está quadrada', ela me bota pra baixo mesmo, entendeu, assim, mas, não porque [...] é coisa de mãe, quer proteger, é, assim mesmo [...]

PESQUISADORA: Você tinha quantos anos?

PRISCILA: Tava com... tava com dezesseis, dezesseis anos. Aí.. eu fui, né, dá aula...quer dizer eu ia fazer dezesseis, eu tava com quinze ia fazer dezesseis, ai fui comecei a dar aula, chegou em casa, eu peguei menti pra minha mãe, porque eu sabia que ela não aceitava, menti pra ela, disse que eu estava fazendo um curso de informática, eu nunca fiz esse curso de informática, eu estava dando aula pra esses meninos.

Diante de uma rotina diária de exercícios físicos, o resultado físico mais imediato é o fortalecimento dos músculos, e, consequentemente, a quebra de um modelo de feminilidade envolvendo as convenções de gênero definidas para o ser mulher, frágil (no sentido de delicada) e fraca (no sentido de pouca força), modelo que envolve aspectos como submissão e invisibilidade.

Esse modelo de feminilidade é transformado visivelmente através da musculatura e contornos corporais das b-girls. Esse é 
um dos aspectos visíveis em seus corpos devido à sua rotina de exercícios físicos exibidos nas coreografias do breaking dancing.

O preconceito de alguns homens em relação às mulheres que desejam se inserir no movimento também encontrou força dentro de casa, por entes da família, quando esta ideia de que o espaço e ações do hip-hop, a exemplo da dança, não seria um espaço para as mulheres. Priscila compartilha sua experiência em relação à prática do break.

Eu sendo mulher e falando da minha relação com os rapazes do hip-hop, ainda mais na localidade onde eu moro, às vezes, é um pouco assim, de transar, porque os meninos do hip-hop, você sabe como é, não gosta de ver menina nenhuma no break. Ainda mais, quando a gente dança melhor que eles, eles já não gostam, acham que a gente está tirando onda, acham que a gente fica querendo saber demais e eles são melhores, os gostosões da parada, porque eles dançam, as meninas gritam, então, eles se sentem mesmo, né. Aí, quando a gente vai dançar, eles acham ruim, né? Então, de vez em quando eu encontrava um, era difícil, eu encontrar um que falasse, assim 'não, você dança legal, dance aqui comigo, venha, entre em meu grupo, porque a maioria é sai daqui', menina sai, nem venha, entendeu? Geralmente, é assim.

Na fala da $b$-girl Priscila, apareceu, mais uma vez, a ideia da invasão das mulheres em um espaço que era exclusivo dos homens, reconhecendo que sua presença transgredia as convenções de gênero no hip-hop, desafiando a ideia de que o break não é um espaço para as meninas. 
Entre as $b$-girls de maior destaque no meio do movimento Hip-hop soteropolitano nos últimos anos estão ${ }^{54}$ Negramone, Josy e, também, Tina, responsável pela roda de break que ocorre no Pelourinho e que desenvolve juntamente com seu namorado, b-boy Ananias, com quem produz a grife de roupas "Hip-hop".

Outro aspecto muito destacado nas falas das hip hoppers em diferentes elementos, inclusive no break, é com relação às referências de outras mulheres no hip-hop e ao reconhecimento de seu próprio trabalho como referência para outras mulheres.

PRISCILA: Humhum [afirmativo]. É realmente lá, onde eu moro, como não existe nenhuma B-girl e eu sou, assim a única lá em São Cristóvão, então eu acho que realmente eu sou importante pra que não deixe essa cultura morrer e pra que, também outras meninas possam se espelhar em mim, e tentarem ser B-girls, também. Porque eu acho que... como eu sou a única e tô lutando, tô sofrendo muito, né? Pelo fato de ser a única, então se as meninas me verem lá, lutando, elas podem se espelhar em mim, e nunca desistir, nunca desistir de correr atrás, só pelo fato de que tem alguém criticando. Eu acho que na vida a gente tem vários degrais, vários testes e a gente tem que subir estes degraus, tem que pular essas barreiras, subir essas paredes / [...] Quando, tipo isso aí, agora veio Fabiana, de Brasília, a B-girl e deu uma expectativa enorme pra gente, entendeu, eu tava meio pra baixo, já fiquei já mais pra cima. Pôxa, velho, ela dança pra caramba! Quero ficar, assim exatamente como ela, quero dançar completamente como ela ou quem sabe, melhor que ela, entendeu? muito bem. Lá em São Cristóvão não

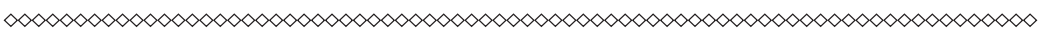

54 As duas b-girls participaram do Curso de Formação de B-girls, no qual Negramone foi a principal idealizadora e responsável do planejamento. Josy atuou de forma relevante nos primeiros momentos do curso, porém, devido à sua primeira gravidez, não pôde dar continuidade à sua participação. Tina também foi convidada para dar aulas de break, mas devido à falta de apoio do namorado, também b-boy, não teve sua efetivação no curso. 
tenho muitas influências, não. Porque a galera lá não tem muito contato, assim, quer dizer na verdade, contato até tem, só que eles não dão valor. Nem todo mundo dá valor. A maioria lá, na rua onde eu moro, assim, a galera dá valor a pagode, arrocha, essas coisas, assim e não a dança do break. Então, eu acho que isso, ai, que me bota pra baixo, entendeu? Quando tô dançando, (fazendo alguma coisa) e a galera não leva a sério, dá risada, vai falar que isso não é pra mim, que eu deveria me comportar, coisa e tal, além do mais, até minha mãe, mesmo, ela reclama muito.

A turma do curso de formação de $b$-girls teve a oportunidade de receber a b-girl "Fabi Girl”, de Brasília. Conhecida por participar de campeonatos internacionais de dança de rua, e por participar de um grupo de break composto apenas por mulheres do Distrito Federal, Fabiana trocou experiências com as jovens iniciantes $b$-girls, mostrando algumas possibilidades de atuação e trabalhos com essa arte da dança como uma alternativa profissional.

Para tanto, como um suporte para se pensar as formas de uso das artes do hip-hop, uma das questões bastante em voga apresentadas pelo movimento foi a preocupação com o estudo sobre o próprio hip-hop. É comum esta relação em torno de textos, indicações de filmes, leituras sobre o tema.

É um contato assim, que, pôxa, fortalece bastante, porque outras meninas vão ver isso, e elas vão perceber que elas não conseguem. Então vai ser tudo, pra outras meninas vai ser tudo. Que às vezes elas se sentem só, eu lá em São Cristóvão, eu me sentia muito só, às vezes. Eu ficava perguntando - Pôxa, Robson... - Robson sumia, velho. David sumia, - Pô gente, não se afaste de mim, não. Porque sem vocês aqui eu me sinto só - Ficava brincando com 
ele - pô, Robinho, passe mais lá em casa, nego. Converse comigo sobre a história do hip-hop. Até um livro de hip- hop que ele deixou para mim ler, coisas. Eu falava - toda informação que tiver traga para mim, pô. Não suma, não, sente aqui, converse comigo, eu ficava caçando a galera do hip-hop, pra mim me sentir bem. Porque quando eu tava sozinha, era bastante discriminada, e eu, sempre, e eu como tenho depressão, então é fácil d'eu entrar em uma crise, eu chorar, entendeu? Eu me sinto só, pô. Então eu ficava falando direto com Robinho - Pô, Robinho não suma, não, fica aí, conversa comigo, e coisa e tal. Passava direto na casa de David, a gente conversava sobre hip-hop. A gente falava de Munegrale, falava da Rede Aiyê, e eu sempre querendo conhecer a banda-Rapaz, me fale dessa banda, rapaz, como é que é isso e coisa e tal - entendeu? Ai, pôxa, na correria, aí, até que finalmente, eu conheci a galera do Munegrale, conheci esse grupo aí, a galera da Rede Aiyê, adorei, Eu acho muito importante mesmo pra quê as meninas possam ver e tomar isso como base e ficar fortalecida. (Priscila)

O caso de Priscila é bem ilustrativo para se pensar as convenções de gênero em torno da feminilidade e da masculinidade na sociedade, e também no âmbito do movimento Hip-hop soteropolitano, a partir de suas aulas de break. Ela mora na comunidade de São Cristovão, um bairro de periferia localizado nos limites entre Salvador e Lauro de Freitas, de numerosa população, afastado do centro da cidade e conhecido por altos níveis de problemas sociais. As aulas acontecem no mesmo bairro, Priscila conta como foi sua experiência com o projeto Escola Aberta, ${ }^{55}$ desenvolvido na

$\infty<\infty<\infty<\infty<\infty<\infty<\infty<\infty<\infty<\infty<\infty<\infty<\infty<\infty<\infty<\infty<\infty<\infty<\infty<\infty<\infty<\infty<\infty<\infty<\infty<\infty<\infty<\infty<\infty<\infty<\infty<\infty<\infty<$

55 Desenvolvido nas escolas públicas - em diversos estados brasileiros - a partir de articulações entre o Ministério da Educação, a Secretaria da Educação do Estado da Bahia e a Unesco, com caráter de atividades extras aos horários regulares da Escola, aberta as comunidades. Disponível em: <http://www.educacao.escolas.ba.gov.br/node/361>. 
escola pública do bairro como uma atividade extra, aberta para a comunidade, sendo ela a única $b$-girl da comunidade e ainda professora de break nessa oportunidade.

PESQUISADORA: Quem é esse público?

PRISCILA: Tinha criança de dez anos, tinha adolescente de dezessete, dezesseis até vinte anos, tinha até senhor de idade, lá, de cinquenta anos, tinha [...]

PESQUISADORA: E qual o sexo?

PRISCILA: Homens e mulheres. De começo tinha bastante homem, depois começaram a vir as meninas e aí ficou uma concentração legal de meninos e meninas. Com o passar do tempo os meninos foram sumindo ficou mais meninas que meninos, ai agora o projeto encerrou, aí voltou de novo, entendeu? Mudou de dezesseis pra dezessete, agora entrou mais meninos que meninas. Então esse ano eu resolvi fazer divulgação nas escolas, até nas escolas de São Cristóvão comecei a divulgar: 'Gente tá tendo um curso de graça de formação de B-boy e B-girl na Escola Parque de São Cristóvão', e aí, chamei, fui de escola em escola pelas manhãs, pelas tardes, fui de sala em sala comunicando isso e ainda fazendo demonstração do que era o break, falando o que era o hip-hop, quantos elementos que compõe o hip-hop, tudo isso, pra galera se interessar, peguei uma lista passei, [...] interessado assine aqui, a galera assinou... e, aí hoje que eu vou me encontrar com essa galera toda, ai, das escolas [...] mais tarde, daqui a pouco eu tô lá na Escola São Cristóvão pra dar aula pra esses meninos. Então, o projeto lá eu tô numa correria sozinha. 
Priscila expõe a reação de seus estudantes com o primeiro contato em busca de suas aulas, e faz observações sobre o estilo hip-hop de ser:

É uma coisa que eu acho interessante. Veja bem, é, os meninos de começo, não aceitava muito isso, não, entendeu? Quando ouviu falar 'tá tendo aula de break, aí, e os meninos 'nossa, vamos lá, que massa', quando chegam lá, 'ah, é uma mulher?'. Pelo amor de Deus, todo mundo queria sair, aí, falaram assim: 'não, péra, aí, péra aí, bóra ver, né?', 'bóra ver como é isso aí' e aí foram. Passado um tempo eles foram gostando, vendo que não tinha nada a ver, negócio [...] de ser homem, de ser mulher, entendeu? Foram, gostaram e continuaram e de começo só tinha menino, chegou a mãe de uma aluna, lá, olhou assim, ai falou: 'Que nada, vou botar minha filha aí, não. No meio desses marginais, tanto vagabundo na sala, cheio de brinco, de correntes, de roupa folgada. Não vou, não vou deixar minha filha, aí, não.' Falou, bem assim. Eu fiquei assustada com a situação. Olhei, assim, é... também não falei nada, né? Fiquei na minha. Depois eu cheguei comentei com os meninos e coisa e tal. Aí, a secretária conversando com a mãe da menina, né? Passado um tempo, aí, sim, conseguiu deixar com que a mãe liberasse a menina pras aulas, porque ela não queria deixar a filha dela lá.

Priscila já tinha completado dois anos de aulas no Projeto, e já tinha estudantes mulheres em suas aulas de dança, o que aponta a repercussão de seu trabalho e reconhecimento da abertura desse espaço de lazer e cultura para as jovens de seu bairro. Quando questionada sobre a diferença entre o comportamento das mulheres e dos homens nas aulas de break, ela responde: 
Mulheres e mulheres... Vejamos, eu acho que no hip-hop as meninas, com as outras é uma coisa, é uma coisa melhor, é bem mais legal, assim, porque as meninas elas se unem. Elas sempre se unem, conversam, trocam algumas ideias, trocam informações, assim, trocam atividades, muitas, muitas, muitas relações, eu acho que uma ajuda a outra, é um comportamento super legal, lá na escola mesmo, eu vejo direto isso. Quando eu falo assim, quando passo um trabalho - gente, faz uma pesquisa e coisa e tal - as meninas são as que mais pesquisam, elas se juntam, formam as equipes delas sozinhas, já os meninos ficam todos desnorteados, entendeu? Eu, eu que tenho de ir, lá, formar equipe pra eles, eu que tenho que intervir [...] Ai, geralmente quando eu passo alguma coisa, assim, as meninas são as que mais correm atrás, e elas se unem bastante, já os meninos brigam até um com o outro. 'Não vou fazer nada com esse cara, não. Que nada, rapaz, com um marmanjo desses, que é que isso, que aquilo.', já as meninas, não: 'venha, fia, umbora fazer comigo', entendeu? Elas se unem mais do que os meninos.

É interessante constatar essa concepção de união feminina da $b$-girl com a desunião apontada pela grafiteira. Uma hipótese para essa disparidade de percepções deve-se ao fato da maior presença, e há mais tempo, de mulheres na prática dos referidos elementos. Talvez o fato de as $b$-girls enfrentarem há mais tempo as convenções de gênero no break possibilite a elas já desfrutarem de algumas conquistas, mesmo ainda sofrendo com algumas sanções oriundas das transgressões que impõem ao hip-hop.

Interessa, ainda, destacar que impõe a relevância da sua prática no desafio mais densamente relacionado a modelos de feminilidade vigentes. Ao transformarem seus corpos, dotando-os de atributos e sentidos comumente associados ao masculino, à força 
e agressividade, estão introduzindo novas possibilidades às convenções de gênero já normatizadas e naturalizadas. Tais desafios e novidades podem ressignificar, também, padrões de conjugalidade e convenções de sexualidade. A análise a seguir nos traz mais dados para se refletir nesse sentido.

\section{Militante objeto sexual - "A carne na frente do leão"}

No elemento militância do movimento Hip-hop não há uma necessidade de envolvimento com um elemento específico, ou mesmo há a possibilidade da criação de um novo elemento. Como representantes do elemento militância do hip-hop soteropolitano, apresento Vivian e Eliciana.

Ambas têm uma longa trajetória no movimento, porém não assumiam a prática de nenhum dos elementos clássicos do hip-hop. No caso de Vivian, a hip hopper produziu inúmeras atividades do movimento na cidade e chegou a representar o hip-hop soteropolitano em encontros em outros estados, mas não chegou a se especializar na arte que mais aprecia dentre os elementos clássicos do hip-hop.

Vivian é admiradora da arte que mixa diversas batidas e que agita os bailes black. A respeito do trabalho das djeias, está vinculado à criação e apresentação das batidas musicais dançantes ao lidar primeiramente com equipamentos tecnológicos - não exatamente instrumentos musicais, mas equipamento de som e outros materiais -, embora haja DJs que trabalham apenas com computador e arquivos e programas musicais.

Entretanto, é rara a atuação de djeias em Salvador, visto que há dificuldades em adquirir o kit DJ com pickup, caixas de som, acervos de vinil e outros. Essa situação pode ser justificada pelo seu excessivo valor no mercado, mesmo quando se refere a 
um material já em uso, afastando a possibilidade de que jovens da periferia, homens e mulheres, tenham chances de comprar esse $k i^{56}$ e se tornem djeias e DJs. Esses critérios inviabilizam a expansão dessa arte, resultando na praticamente inexistência de djeias soteropolitanas. ${ }^{57}$

A partir desse contexto, o hip-hop apresenta novas configurações de militância e cria novos elementos na sua interação entre política e cultura. É o caso de Eliciana, que nos apresenta um novo elemento embutido no hip-hop soteropolitano. A hip hopper se apresenta como Vjeia, sendo o masculino o termo $\mathrm{VJ},{ }^{58}$ que pode ter referência nas djeias e DJs.

Enquanto a djeia realiza seu trabalho ligado a discos, geralmente com vinil e pickup, a Vjeia atua com filmagens e criação de imagens do movimento com câmeras de vídeo e máquinas fotográficas. É o que explica Noronha (2007, p. 189) diante da

possibilidade de entender os circuitos e a lógica dos rappers (e hip hoppers) na cidade tornaram evidente a ideia de que o hip-hop não era algo homogêneo, mas constituído por jovens que apresentavam diferentes discursos linguagens artísticas e formas de organização.

Vale ressaltar que há a legitimação do elemento militância para além da necessidade de criação de um novo elemento, sendo o caso de Vivian. Ela atua nas articulações do movimento na cidade e fora dela, bem como produz atividades, projetos e documentos

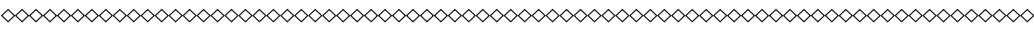

56 Além desse kit djeia, com pickup (toca-discos vitrola especial para samples), vinis (quanto mais antigos e raros, mais caros) e cases (caixas de proteção apropriadas) para transporte, há o próprio custo do transporte, em caso de pagar frete, táxi ou mesmo pagar a gasolina no caso de uma carona, o que afasta a tentativa de muitas - e muitos - hip hoppers no investimento do desenvolvimento dessa arte.

57 É possível encontrar djeias soteropolitanas nos estilos techno e/ou eletrônico, não sendo parte da cultura hip- hop.

58 Vj seria um Video Maker Musical, uma mestre de cerimônia que apresenta videoclipes contando sobre músicas e artistas. Pode ser também uma pessoa que produz esse próprio material audiovisual. No entanto, esse não é um dos quatro elementos do hip-hop. 
em nome do movimento, além de sua representação ser reconhecida como hip hopper. É o que explica Eliciana:

ELICIANA: Só a militância.

PESQUISADORA: Só?

ELICIANA: Hum, hum só. [risos]

PESQUISADORA: Tu pode assim pensar um pouco esse elemento, falar um pouco sobre esse elemento?

ELICIANA: Eu acho que..., por a... a velha guarda como diz, que o hip-hop tem quatro elementos, mas assim no meu ver que... esses quatro elementos não andam sem a militância, porque, assim a maioria das pessoas que eu conheço, como Simone, Paula, todo mundo faz parte de um elemento e não esquece a militância. E se não militar pra onde vai o hip-hop? Vai ficar só... na dança na música e mais nada. E tem que ter a parte do correr atrás, é aí de onde vem a militância. Sempre tem pessoas dentro do hip-hop que só faz a militância, que não se... que não se identifica com os quatro elementos, mas gosta da ideologia e da militância.

A militância é responsável pela constituição do hip-hop como movimento social, pois ultrapassa os limites de uma cultura hip-hop que se apóia na produção de suas artes. É o elemento que permeia todos os outros elementos artísticos do movimento Hip-hop. Porém, é a partir da experiência de militância de Eliciana, apelidada de Lis, que observaremos um caso ocorrido durante o desenvolvimento de um dos seus trabalhos de vídeo, voltado para seu trabalho de militância como representante do movimento Hip-hop. Esse caso foi chamado de "A carne da frente 
do leão", por questionar as convenções de gênero e de sexualidade e a legitimidade das mulheres como militantes no hip-hop.

Eliciana gostava de rap e funk quando criança, e durante o trabalho de campo flagrei ela brincando com rimas e "mandando" 59 muito bem no freestyle (improvisação). Como dançarina de rua aos dez anos de idade, ela chegou a participar de um grupo de funk, chamado Funk cobra girls, no qual dançou em um dos primeiros bailes black da cidade. ${ }^{60}$

No decorrer de seu envolvimento com o elemento social ou político do hip-hop, ela participou de produções de inúmeros projetos e eventos do Movimento. Entretanto, seu trabalho principal foi com a produção de documentários, entre eles, III Encontro de Gênero e Hip-Hop, A saga da casa do Hip-Hop e Hip-Hop em sete vidas, dentre outros. Eliciana nos conta o caso:

Assim, eu, por exemplo, que estou produzindo esse documentário, assim, é muito difícil a gente não ser vista como símbolo sexual, a gente mulher, não tem jeito, é foda, lugar de trabalho, onde for. No meio do hip-hop, por exemplo, nesse processo de produzir o documentário, eu estou conversando com os caras, não dá pra eu ter uma conversa só de militante pra militante. Como é que tá o movimento aí, num sei que, a gente tá fazendo isso, fazendo aquilo. O cara vê você como, no meio do hip-hop como 'uma mulher pros caras' sabe? Vê assim. E recentemente passei por uma situação com uma figura famosa, que eu tava entrando em contato pra entrevistar; ele que não é daqui, eu já conhecia ele, ele já me conhecia de outros eventos de que eu participei e ele perguntou se eu ia fazer um Tour com ele em Salvador e eu perguntei pra

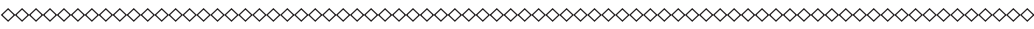

59 "Mandando", gíria no movimento para um resultado positivo, compondo letras e expondo-as ao cantar livremente.

60 Esse episódio terá atenção no próximo capítulo. 
ele se essa era a condição pra fazer a entrevista de que eu precisava. Porque era isso que ele tinha entendido, o que ele queria, que a gente fizesse uma troca. Eu fazia a entrevista que eu queria pra o documentário e me vendia pra ele, embora a gente tivesse falado tanto de movimento social, de militância e tal, enfim [...] embora fosse militante e eu, depois que eu fiz essa pergunta ele: 'não, não quero que você entenda assim, me desculpe, me perdoe, eu reconheço como você é guerreira, num sei que, num sei que, num sei que, você vai fazer a entrevista!' E durante o dia que eu passei com ele, que eu acompanhei o processo todo, ele não parou de me cantar! Então, aconteceu a entrevista [...] mas eu era mulher e isso faz com que tudo que exista de militância, de pessoal profissional, de qualquer coisa, de mulher forte, caia pra ser simplesmente uma pessoa que ele vai cantar você, fazer sexo e pronto. Enfim, é a gente tentar todo dia não, é você ser a carne na frente do leão e tentar dialogar com ela ao mesmo tempo e o leão quer te comer, porque não enxerga você como nada além do que uma carne que ele quer comer. É foda.

Este significante de objetificação e disponibilização sexual do corpo feminino, como "uma mulher pros caras", é questionado pelas mulheres hip hoppers, que transgridem essa convenção ao adentrarem no espaço do movimento com objetivos mais direcionados à sua própria militância e formação profissional. Eliciana demonstrou em sua experiência que "não dá pra eu ter uma conversa só de militante pra militante" Isso se confirma nas formas de objetificação do feminino, em especial das mulheres negras, significadas pelas convenções de gênero e sexualidade.

Ao considerar um homem "famoso" e ainda mais "turista" na cidade de Salvador, a representação da militante tomou forma de "carne na frente do leão". Mesmo o hip hopper em questão, 
que na mídia fomenta o nome do movimento Hip-hop ao que, reivindicando transformação social e combate às discriminações, reforça as convenções de gênero que dão significado ao modelo de masculinidade potente, caçador, implacável e galanteador, mesmo diante de um contato de trabalho, portanto, espaço de militância do movimento.

A militância da hip hopper, minimizada a elemento de troca por prazer em detrimento de informações sobre e para o movimento, perdeu importância diante do hip hopper que apenas "não enxerga você como nada além do que uma carne que ele quer comer". Ao questionar o comportamento do entrevistado, a Vjeia contestou o modelo de masculinidade e de feminilidade posto por uma lógica de gênero ao reformular a postura dada à sua militância.

Diante dessas e de outras questões que envolvem a militância das mulheres jovens no Hip-hop, as experiências relatadas mostraram as motivações e oportunidades de atuação das mulheres nas artes e na militância desse movimento social, ao passo que dialogam com as convenções de gênero no hip-hop, que em alguns momentos são reforçadas e, em outras ocasiões, reformuladas diante de situações e casos vivenciados pelas hip hoppers.

Como se pode perceber na análise das situações apresentadas, o primeiro passo em direção à contestação das convenções de gênero é a própria presença das mulheres, o que pode ser entendida na chave analítica de Anne Phillips (2001), a qual trabalha com a distinção entre a política das ideias e a política da presença.

Segundo Phillips, há uma crescente exigência democrática por "presença política" pelos grupos marginalizados ou excluídos historicamente de participação, a exemplo de mulheres e negros. Diante dos problemas da igualdade política, a autora afirma,

[...] a separação entre quem e o quê é para ser representado, bem como a subordinação do primeiro ao segundo, está em 
plena discussão. A política de ideias está sendo desafiada por uma política alternativa, de presença. (PHILLIPS, 2000, p. 5, grifo do autor)

O embate para garantir a participação das mulheres no movimento é assumido pelas hip hoppers, como se pode acompanhar através do relato de Dina:

Eu acho que é o que todas as meninas enfrentam entendeu? É de você ocupar os espaços, é de mostrar para os caras que aqueles espaços que eles dizem que são nossos, é nosso, não é porque eles estão dizendo, é porque já era nosso, então a maior dificuldade fazer com que eles percebam que aquele espaço já era estabelecido, aquele espaço de mulher no Hip Hop, porque os meninos já vem dando migalhas, faça isso, faça aquilo, nós temos que ocupar aquele espaços, nós temos que discutir relação de gênero naquele espaço, é nosso!.

Assim, esse movimento oportuniza, por meio de suas linguagens, diversas formas de análise acerca das convenções de gênero. Apreendendo a consideração da rapper acerca das "migalhas" dadas pelos meninos, é oportuna a reflexão acerca da questão hip-hop: espaço de contestação das convenções de gênero? 